\title{
Osmanlı İltizam Sözleşmelerine Yansıyan Yönleriyle Yahudi Girişimciler (I 560-I630) (7 Belge ile Birlikte)
}

\author{
Zafer Karademir*
}

Jewish Entrepreneurs as seen in the Ottoman Tax-farming (Iltizam) Contracts (15601630) (With 7 Documents)

\begin{abstract}
There were many groups with different ethnic or religious origins among the subjects Ottoman Empire. One of those groups, the Jews, contributed significantly to the economic structure maintained by the state especially in the fields of finance and production. Their position as capital holders helped them to place bids frequently for tax-farms (iltizam) in the sixteenth and seventeenth centuries. The Jews who placed many tax-farming bids in partnership with their coreligionists or Muslims faced certain economic and legal difficulties, or became the source of the problem themselves in the processes. The official attitude was to keep them in production economy as much as possible in these distressed times. The state needed the Jewish entrepreneurs because of their capital, and this group stayed in the iltizam bids persistently. One can say that both sides believed that the continuation of the system would be to their mutual benefit, and they saw the termination of the tax-farming bids as the last resort. The texts on tax-farming bids examined here provide interesting details about how the state protected the Jewish tax-farmers who fell into financial difficulty.
\end{abstract}

Keywords: Ottoman, Jews, Tax-farming, İltizam, Mukataa, Tax-farmer.

\section{Giriş}

Erken Osmanlı Çağında Yahudiler ve İltizam Sistemindeki Yerleri

Daha kuruluşunun ilk temelleri atıldığı sıralarda Osmanlı tebaası, birbirinden farklı etnik ve dini aidiyetleri bulunan halklarla şekillenmeye başlamıştır.

* Cumhuriyet Üniversitesi 
Yahudi milleti de bu zengin yapı içerisinde erken dönemlerden itibaren yer almıştır. Orhan Bey'in Bursa'yı fethini müteakiben (1326) Şam’dan ve Bizans imparatorluğundan Yahudiler' in bizzat sultanın davetinin karşılı̆̆ olarak kente yerleşmelerine dair bilgiler ${ }^{1}$ ya da dönem yazarlarından birinin Yahudiler'in II. Mehmed saltanatıyla birlikte Osmanlı idaresinde önceden sahip olmadıkları ayrıcalıkları elde ederek "padişahın işlerine karışmaya başladıklarını" kaydetmesi, ${ }^{2}$ erkenden başlayan ortak tarih inşasının küçük nüveleridir. ${ }^{3} 1492$ yılında İspanya'dan gelen Yahudiler'in imparatorluk arazilerine yerleşmeleri, iktisadi yaşamdaki tecrübelerini kısa sürede yansıtmaları sayesinde bahsedilen yakınlığı daha da artırmıştır. ${ }^{4}$

Yahudiler'in Osmanlı sınırlarının güven ortamında Bursa'da verimli baharat ve tekstil ticaretinde rol almalar $1,{ }^{5}$ özellikle İstanbullu Yahudi tüccarların Akkirman, Kefe ve Kili gibi görece uzak diyarlardan mal getirmeleri ${ }^{6}$ ve $1520-1530$ rakamlarına göre İstanbul ve Selanik kentlerinde Yahudi nüfusunun yoğunlaşma$s^{7}$ devletin izlediği himayeci siyasetin gerçek hayatta karşılığını bulduğunu göstermektedir. Bu politikada Yahudiler kendilerine sunulan ortamda rahat hareket edebilme fırsatını değerlendirirken, sultanlar da imparatorluğun ticari kapasitesini büyütmek adına onların iktisadi üstünlüklerinden ve girişimci yapılarından faydalandilar. ${ }^{8}$

1 Eva Groepler, İslàm ve Osmanlı Dünyasında Yahudiler, çev. Süheyla Kaya (İstanbul: Belge Yayınları, 1999), s. 29. Kimi yazarlara göre 1453-1602 süreci Yahudiler'in imparatorluktaki en müreffeh dönemini nitelemektedir.

2 Aşııpaşaoğlu'na göre Fatih devri vezirlerinden Yakub Paşa ile birlikte bu gerçekleşmiştir. Tevârih-i Âli Osman'dan Aşskpaşazâde Tarihi, Matbaa-i Amire, İstanbul 1332, s. 192. Hakkında bkz. Mecdi Efendi, Şakayık-ı Numaniye Tercümesi, İstanbul 1269, s. 237.

3 Bizzat II. Mehmed'in İstanbul'un fethinden hemen sonra Asyalı Musevileri kente yerleşmeye çağırması da aynı anlamda değerlendirilebilir. Groepler, İslâm ve Osmanlı Dünyasında Yahudiler, s. 30 .

4 Minna Rozen, A History of the Jewish Community in Istanbul: The Formative Years, 1453-1566, Leiden 2010, s. 237.

5 Rozen, A History of the Jewish Community in Istanbul, s. 226.

6 Halil İnalcık, "Bursa and the Commerce of the Levant", Journal of the Economic and Social History of the Orient, vol. 3, no. 2 (1960), s. 136.

7 Barkan'dan nakleden: Bernard Lewis, İslâm Dünyasında Yahudiler (Ankara: İmge Kitabevi, 1996), s. 138. Selanik için "Küçük Kudüs" denilmesi bunun yansıması olmalıdır. Bkz. Stanford J. Shaw, The Jews of the Ottoman Empire and the Turkish Republic, New York 1991, s. 100.

8 Robert W. Olson, "Jews in the Ottoman Empire in Light of New Documents", Jewish Social Studies, vol. 41, no. 1 (1979), s. 76. 
Buraya kadar bahsedilen makro iktisadi ve sosyolojik yakınlaşmalar ayrıntılara inildiğinde daha net görülebilmektedir. Daha açık bir ifadeyle Yahudiler, bu çalışmanın ilgilendiği temel iktisadi faaliyet alanı olan iltizam ihalelerinin de talipleri ve sahipleri arasında yerlerini aldılar. Zaten onlar henüz dışarıdan kitlesel göçler başlamadan bile vergi denetimi ve tahsilinde görev almaya başlamışlardı. ${ }^{9}$ Osmanlı iktisat düzeninin bel kemiği olan iltizam sistemi önemli bir sermaye girdisi ile yürütülebilen bir ekonomik yapı olması hasebiyle, güçlü sermayeleri elinde tutan Yahudiler'in hemen ilgisini çekmiştir. Terim olarak "özel bir şahsın devlete ait herhangi bir vergi gelirini toplamayı belirli bir yıllık bedel karşılığında üzerine alması” demek olan iltizam düzeninde" ${ }^{10}$ bahsedilen gruplar devlet tarafından da mültezim olarak tercih edilmişlerdir. Bunun neticesinde Yahudiler'in belki de biraz şartların öyle gerektirmesi nedeniyle ${ }^{11} 14$. ve 15 . yüzyıllarda özellikle gümrükler başta olmak üzere imparatorluk iltizam ihalelerinde aktif rol oynadıklarını1 ${ }^{12}$ ve 15 . yüzyılın sonlarından itibaren artık milyonlarca akçelik ihaleleri alan mültezimler rolüne büründüklerini görmek mümkündür. ${ }^{13}$ Askeri kökenli olan Müslümanlar başarısız ya da yetersiz olduklarında yerlerini hemen Yahudi mültezimlerin alması da devletin tebaasının liyakatine olan güveninin bir göstergesiydi. ${ }^{14}$ Yine Yahudi kadınların da iltizamlarda boy göstermeleri bahsedilen grubun girişimciliğine dair ilginç ve güzel bir başka veridir. ${ }^{15}$ Dolayısıyla

9 Groepler, İslâm ve Osmanlı Dünyasında Yahudiler, s. 36.

10 Mehmet Genç, "İltizam”, TDV İlam Ansiklopedisi, 2000, XXII, s. 154.

11 Matuz’a göre, Yahudiler toprak mülkiyeti ya da büyük idari pozisyonları elde edemeyeceğinden elinde sermaye olanlar için en iyi yatırım aracı iltizamlardı. Joseph E. Matuz, "Contributions to the Ottoman Institution of the İltizam”, Osmanlı Arassttrmaları XI (1991), s. 247. Herhalde tüccarlık ve sarraflık gibi bazı alanları bunun dışında tutmak gerekir.

12 Aryeh Shmuelevitz, The Jews of the Ottoman Empire in the Late Fifteenth and the Sixteenth Centuries (Leiden: Brill Publishing 1984), s. 108, 109.

13 Rozen, A History of the Jewish Community in Istanbul, s. 239. Musevi girişimcilerin bu şekilde mali güçlerini ortaya çıkarmaları ve bunu genişletmelerinde İstanbul'un fethi tetikleyici bir rol oynamıştır. Halil İnalcık, Osmanlı Imparatorluğu’nun Ekonomik ve Sosyal Tarihi Cilt 1 1300-1600, çev. Halil Berktay (İstanbul: Eren Yayınları, 2004), s. 260. Aslında bu rolleri birer "idareci" olarak devletin kademelerinde varacakları en son basamaktı. Yaron Ben-Naeh, Jews in the Realm of the Sultans: Ottoman Jewish Society in the Seventeenth Century, Tübingen 2008, s. 149.

14 Haim Gerber, "Jewish Tax-Farmers in the Ottoman Empire in the $16^{\text {th }}$ and $17^{\text {th }}$ Centuries", Journal of Turkish Studies (1986), vol. 10, s. 151.

15 Bkz: İnalcık, Osmanl İmparatorluğu’nun Ekonomik ve Sosyal Taribi, I, s. 265. 
ihalelerin kimde kalacağ 1 konusunda bir tercih yapılırken kişinin menşeinden ziyade mali sicili önemliydi. ${ }^{16}$ Bunun bir başka yansıması olacak şekilde, çağdaş terminoloji ile ifade edilecek olursa, ihalelere fesat karıştırılması, nereden gelirse gelsin kabul edilemez bir durumdu. ${ }^{17}$

Görüldüğü üzere Osmanlı toplumundaki Yahudi müteşebbisler aktif tavırlarının ve Osmanlı idarecileri nezdindeki olumlu sicillerinin etkisiyle güçlü birer mültezimler olarak sistemin içinde sağlam yerler edindiler. Ancak bu genel çerçeve içinde Yahudi mültezimlerin ihaleleri elde etmeden önce, elde ettikten sonraki işletme süreçlerinde ve sonrasında devlet ile olan münasebetlerinin ne yönde geliştiği, daha sarih bir anlatımla, iltimasla korunup korunmadıkları ya da tam aksine kimi zamanlarda ve yerlerde hak ettikleri halde engellenip engellenmedikleri gibi durumlar pek açıklığa kavuşmamış konulardır. Ayrıca mültezimlerin ihalelerinde başarılı olduklarında nasıl hareket ettikleri ya da başarısız iltizam yönetimlerinde ne gibi hukuki yaptırımlarla karşılaşıklarına dair bugüne kadar ulaşan bilgiler hep sistemin genel yapısı içinde çok kaba hatlarıyla ifade edilmiştir. Yine üzerinde pek durulmayan hususlardan biri de Müslüman tebaa ile Yahudiler arasındaki mali ilişkilerin iltizam sözleşmelerine sahip olunması ve bunların işletilmesi döneminde ne yönde seyrettiğidir. Nihayet devletin sermayedar Yahudiler'in sistem içindeki problemleri aşmalarında ya da bizzat kendileri sorun haline geldiklerinde hangi yasal süreçleri ne amaçla işlettiği de araştırmacıların çok söz söylemediği sahalardandır. Dolayısıyla bu çalışma bahsedilen problemlerin aydınlatılması adına iltizam sözleşmelerinin

16 Hicri 1033 (Miladi 1623-1624) yılında Kütahya'da hanedana ait bir şap işletmesinde olduğu gibi stratejik ya da politik önemi bulunan işletmelerin de onlara bırakılması anlamlıdır. TS.MAD, 2575.0007/1-2.

17 Örneğin Hicri 998-990 (Miladi 1589-1582) yılları arasında Koçanya madeni mukataasının mültezimi Derviş ismindeki zat, muhasebesinde zararlı çıkmasına rağmen ısrarla mültezimliğine devam etmekte daha doğrusu ettirilmekteydi. İhaleyi sonradan alan Yahudi Minovil ve ortakları ise iddialarına göre; bir türlü diledikleri gibi mukataalarına hâkim olamamaktaydılar. Yine anlattıklarına göre onları zor durumda bırakan asıl mesele ihalenin müfettişi ve aynı zamanda Derviş’in akrabası olan Belgrad kadısının şahsî nüfuzunu kullanmasıydı. Akrabasını koruması için meslektaşı Koçonya kadısına da mektup gönderen kadı daha öteye giderek başkentteki bağlantılarını kullanmak için oraya gitmeyi de ihmal etmemişti. BOA, MAD 6209/31. İmparatorluk geleneği elbette bir haksızlık varsa buna müsaade etmeyecekti. Müddeilerin dikkatle dinlenmesi ve bir süre sonra özellikle Derviş’in aranması bunu gösteriyordu. 
ayrıntılı metinlerinin bir hayli faydalı olacağını, birkaç örnek üzerinden gösterme gayreti içindedir.

\section{İltizam Hikâyelerine Yansıyan Yönleriyle Yahudi Girişimciler ve Devlet ile Münasebetleri}

Bu noktaya kadar bahsi geçen mültezim Yahudiler'in devlet ile anlaşmalarını içeren mukataa sözleşme ve teklif metinleri tarihsel bilgi bakımından hayli zengin verileri içermekte olup bu tip metinler çoğu zaman iltizam sistemi hakkındaki genel değerlendirmelerin gölgesinde kalmıştır. ${ }^{18}$ Yine Osmanlı iktisat düzeninin sorunsuz yürütülmesi ve bu esnada yaşanan olası ya da olağandışı sıkıntıların halledilmesi sürecinde hangi yolların takip edildiğine dair detaylar da bu metinlerde saklıdır. İşte bu çalışmada Başbakanlık Osmanlı Arşivi’nden temin edilen ve 16. yüzyılın ikinci yarısı ile 17. yüzyılın ilk yarısına tarihlenen beş adet iltizam ihalesi metninin dökümleri üzerinden bahsedilen ayrıntılara değinmektedir. ${ }^{19}$ Metinlerin oldukça teknik ve niceliksel detaylar içeren kısımları, asıl hedeften sapma endişesiyle tümüyle aktarılmamış, buna karşılık çalışmanın amacına uygun her türlü veri de değerlendirmeye dâhil edilmiştir. Metinler "devlet" kayıtları olması yüzünden kuşkusuz resmi tarafın sesini duyurmakla beraber, içerde diğer tarafların ifadelerinin de yer almış olması bu tek yönlülükten bir nebze olsun kurtulmayı sağlamaktadır. Ayrıca, metinleri irdelenen birkaç iltizam ihalesinin sadece birer

18 Hiç kuşkusuz bu tür metinlerin niceliksel verileri hayli fazla incelemeye malzeme olmuştur. Ancak metinlerin kendisi ile doğrudan ya da kısmen ilgilenen az sayıda çalışmaya rastlanmıştır. Birkaç örnek vermek gerekirse: Mehmet Ali Ünal, "XVI. Yüzyıl Sonlarında Bir İltizam Sözleşmesi”, Tarih İncelemeleri Dergisi, 6 (1991), s. 59-77; Halil Sahillioğlu, "Bir Mültezim Zimem Defterine Göre XVI. Yüzyıl Sonunda Osmanlı Darphane Mukataları”, İstanbul Üniversitesi İktisat Fakültesi Mecmuası, 23 (1962-63), s. 145-218; Murat Çizakça, "Tax-Farming and Resource Allocation in Past Islamic Societies", JKAU: Islamic Econ., vol. 1, s. 59-80; Gerber, "Jewish Tax-Farmers..." s. 143-154; Bilgehan Pamuk, "XVII. Asırda Gümüşhane (Canca) Maden Mukataasına Dair Bazı Bilgiler”, Atatürk Üniversitesi Türkiyat Araştırmaları Enstitüsü Dergisi, 30 (2006), s. 167-184; Linda Darling, Revenue-Raising and Legitimacy Tax Collection and Finance Administration in the Ottoman Empire, 1560-1660 (Leiden: E.J. Brill Publishing 1996) s. 126, 136-452.

$19 \mathrm{Bu}$ metinler teklif halinde iken mültezim adaylarının arzı şeklinde olup kesinleştiğinde Mukataa Defterleri diye de bilinen Fihrist Defterleri içinde yer almaktadır. Belge ve defter grupları hakkında bkz. Baki Çakır, Osmanlı Mukataa Sistemi (XVI-XVIII. Yüzyll) (İstanbul: Kitabevi Yayınları, 2003), s. 6-9. 
mali kayıt olmadığını da eklemek gerekir. Nitekim satır aralarına gizlenen ifadeler, mukataa içinde yer alan Yahudi girişimciler ve devlet tarafının hareket biçimlerini, birbirlerine olan güvenin derecesini ya da haksızlık ve başarısızlık gibi olumsuz gelişmelerde tahammül düzeylerini gösteren başka ipuçlarını da içeriyor. Kısaca bu çalışma bahsedilen yüzyıllarda Yahudiler'in mültezimlik rollerini, devletle yaptıkları anlaşmalar üzerinden anlama gayreti içindedir. Bu makalede onların iltizam süreçlerindeki başarı ya da başarısızlıkları ile imparatorluğun üretim-tüketim düzenine etkileri incelenmektedir.

İncelenen metinlerden ilki Hicri 973 yılının 11 Ramazan'ından (Miladi 1 Nisan 1566) itibaren Selanik gümrük mukataası'nı elde eden ancak 3 yıllık sözleşmesinin daha ilk yılında başarısız olarak iltizamdan vazgeçmek zorunda kalan David isimli Yahudi bir girişimciye ait. ${ }^{20}$ Onun başından geçenler, çeşitli açılardan iltizamı yürütemeyecek noktaya gelen kişilere karşı resmi makamların nasıl bir tavır takındığını ve durumun düzeltilmesi adına her iki tarafın hatta üçüncü tarafların yani iltizamı kendi üzerine almak isteyen başka birilerinin pozisyonlarını nasıl belirlediklerine dair önemli veriler sunuyor:

\title{
İltizam 1: 11 Ramazan 973 (1 Nisan 1566) Selanik Gümrük Mukataası ${ }^{21}$
}

Yer:

İltizam Konusu: Selanik Gümrük Mukataası

\section{1. İhale}

\author{
İltizamın Sahibi: David veledi Avraham Yahudi \\ İltizamın Süresi: 11 Ramazan 973'ten (1 Nisan 1566) itibaren 3 ynl \\ Iltizamın Tutar: 450.000 akçe
}

20 Selanik'in, şehirdeki Yahudi tacirler için Balkanlar, Suriye, Mısır ve Filistin bölgeleri ile yoğun bir ticari ağın merkezi olduğunu hatırlamak gerekir. Shmuelevitz, The Jews of the Ottoman Empire, s. 139. Yine imparatorluk genelinde Yahudiler'in adeta limanlara tekel koyarak buralarda amirinden memuruna hatta hamalına kadar yer edindiklerini eklemelidir. Hiç kuşkusuz vergi toplama işi de büyük oranda onların kontrolündeydi. Lewis, İslâm Dünyasında Yahudiler, s. 153.

21 BOA, D.İSM.d., 25364/2, 4, 5. 
İhalenin Şartları: Her sene başında hesap görülmek kaydıyla (sene be sene haklaşmak üzere) David'e verildi.

İhale süreci: İlk yılın sonunda anlaşma şartı gereği mukataanın bir yıllık hesabı ödenmesi gerekirken David bunu yerine getiremeyince 2. ihale planlanmış ve sipahi oğlundan Davud isminde birisine verilmiştir.

\author{
Planlanan 2. İhale \\ İltizamın Yeni Sahibi: Sipahioğlu Davud \\ İltizamın Süresi: 22 Ramazan 974’ten (2 Nisan 1567) itibaren 3 yıl \\ İltizamın Tutarı: 150 bin akçe ziyade ile 600 bin akçe
}

İkinci süreç başlamadan David'in bir yıllık muhasebesi görüldüğünde yılllı ödemesinin (kıste’l-yevm) ancak bir kısmını yapabildiği yani zararının bulunduğu anlaşıımıştır. ${ }^{22}$ David, bir önceki yılın ağır kış şartlarını, sefer hazırlıkları kapsamında hassa top arabalarına bargir temininde yer almasını ve bu süreçte Selanik'e eski yıllardaki gibi tüccar gelmemesini zararının nedenleri olarak anlattı. Yahudi girişimci, yeni yılın ilk iki ayının verilerinin iyi gittiğini belirterek bir önceki seneye ait zararını da ödeyebileceğini ifade etti. "Bunu yapmazsam ihaleyi bana bir daha vermeyin" diye de kararlılığını belirtti. "İlla başkasına ihale edecekseniz bu durumda zararımı ödemeye gücüm yok, şartlar gereği ben zararımı ödemeden yeni iltizam mukavelesi yapılamaz" dedi. Yine bu zararının tazmini için daha önce isimlerini verdiği İstanbul'daki kefillere ek olarak Selanik'te de kefillerinin olduğunu iletti. ${ }^{23}$ "Her şeye rağmen yine sipahiye verirseniz, sipahinin iltizamını ben de kabul ederim. Benden sonra her kim iltizamda kâr elde ederse benim verdiğim kesri eda etmeyince (ödediğim zararı kendi üzerine almayınca) işe başlayamasın" diye de ekledi.

22 Mültezimin mukavelede belirlenen süre içinde her bir yıla ait hesabına kıstelyevm denirdir. Genç, "İltizam", s. 155.

23 O sıralarda (1568 tahririnde) Yahudi nüfusun kentteki oranının \% 63,5 seviyesinde olduğunu anmak gerekir. Ayhan Pala, XV ve XVI. Yüzylllarda Selanik Şehri, Ankara Üniversitesi (Doktora Tezi), 1991, s. 69. Dolayısıyla girişimcinin kentte kendisine yardımcı olacak sermayedar yol arkadaşlarını bulmakta zorlanmamış olması gerekir. 
Böylece yeni ihale yürürlüğe girmeden David'in elindeki beratına bakıldı, şahitler dinlendi. Oradaki kayıtlara nazaran, ihale yine mültezim olarak David'de kalacaktı. Ancak eskisi gibi Selanik gümrük mukataasına ve hassa beytülmale günlük 100 akçeye Şükrullah sipahinin emin olması, Mustafa adındaki bir şahsın hassa beytülmale günde 2 akçeye, Hacı Mahmud adında birisinin de gümrüğe günde 30 akçeye kâtip olarak hizmet etmesi kararlaştırıldı. Anlaşmanın sonuna kadar emin ve kâtipleri mültezimin kendisi seçecekti. ${ }^{24}$ Bir yılın sonunda tahsilâtta eksik çıkarsa kendisiyle devam edilmeyecekti. Bir iki ay içinde eksiğini ödeyebilirse ödeyecek tahsilât kesinlikle diğer yılın sonuna sarkmayacaktır. Bu nedenle şimdilik devlet, kesrinin tahsili işine girişmeyecek ve iltizamına devam edecek. Çünkü ikinci yılın ürünlerinin yeterli gelmesi ve ilk yılın zararının karşılanması ihtimalinin doğmuş olması mühimdir. Zira ikinci yılın ilk iki ayında 300 bin akçelik bir mahsul elde edilmiştir.

Yoğun Yahudi nüfusu ile öne çıkan Selanik kentine ait olan ve gümrük mukataasına David ismindeki girişimcinin mali hayatının bir kesiminde başından geçenleri anlatan bu metin, onun ve devletin bu tip anlaşmalarda hangi pozisyonları ne şekilde aldıklarına dair ilginç şeyler söylüyor. İltizam sözleşmesi üç yıllık olmasına rağmen tarafların yıl dönümlerinde hesap için bir araya gelmesini öngörmüş olması önemlidir. Bu tavır daha çok resmi tarafın, iflas ve terk de dâhil yaşanması olası olumsuzluklara karşı önlemiydi. Tam da bu tereddüdü boşa çıkarmayacak şekilde Yahudi sermayedarın başına istenmeyen vakalar gelmişti. David'in başlangıçta işleri iyi giderken, iltizamının işleyişini aksatan iki önemli olay yaşanmıştı. İddiasına göre mukataanın başarısızlığının sebepleri girişimcinin boyunu aşacak meselelerdi. O yıl (1566) yaşanan ağır kış şartları ve savaş hazırlıklarına destek vermesinin istenmesi belini bükmüş ve ödemesi gereken yıllık meblağda açığı ortaya çıkmıştı. ${ }^{25} \mathrm{Bu}$ iki gelişme nedeniyle kervansaraylar boş kalmış ve kente uğraması gereken tüccar kafileleri ortalıkta görünmeyince daha ilk yılında ödemesi gereken meblağda (kıstelyevmde) açık vermişti. Gerçekten de mukataanın

24 BOA, D.İSM.d., 25364/2, 4.

$25 \mathrm{O}$ dönemlerde sefer süreçlerinin mukataaların gelirini ne denli düşürdüğüne dair Buda kentinden iyi bir örnek için bkz. Klára Hegyi, "The Financial Position of The Vilayets in Hungary in the 16th -17th Centuries”, Acta Orientalia Academiae Scientiarum Hungaricae, vol. 61, no. 1/2 (March 2008), s. 80. 
başladığı 1566 yılının bahar ayları, I. Süleyman döneminin son harekâtı olan Zigetvar Seferi'nin de hazırlıklarının yapıldığı bir dönemdi. ${ }^{26}$ Selanik kenti de imparatorluğun batıya düzenlediği askeri operasyonlarında önemli bir levazım tedarik sahası, deniz yolu ikmal merkezi ve güzergâh koruma üssü idi. ${ }^{27}$ Dolayısıyla mültezimin iddialarında doğruluk payının olması yüksek bir ihtimal gibi gözükmektedir. David'in o yıllarda ağır kış şartlarının yaşandığına dair gerekçesi de yabana atılacak bir iddia değildir. Zira bahsedilen dönemin uzun ve ağır kış şartlarının Akdeniz ve Osmanlı coğrafyasını derinden etkileyen bir iklimsel süreç olduğu yolundaki değerlendirmeler onun haklı olabileceğine işaret ediyor. ${ }^{28} \mathrm{Her}$ ne kadar yılllık periyotlarla sıcaklık ve yağış değerlerine dair niceliksel veriler tutulmamış olsa da incelenen dönemde iklimsel zorlukların Osmanlı üzerindeki etkileri kayıtlara yansımıştır. ${ }^{29}$ Dolayısıyla burada spesifik bir vaka yaşanmış olsa da bu bahsedilen süreçten dolayı şaşırtıcı değildir.

David'in bütün bu açıklama ve taahhütlerinden sonra devlet, elbette itidalli bir şekilde davranarak anlattıklarının doğruluğu ve verdiği sözlerin gerçekleşebilmesi ihtimali konularında tetkik yapma ihtiyacı hissetmişti. Selanik kadısına, David'in zararını karşılayama kefil olanların hakikaten buna güçlerinin yetip yetmediğinin yerinde incelenmesi hususunda emir çıkartılmıştır. ${ }^{30}$ İltizam

26 Peçevî İbrahim Efendi, Tarihi- Peçevî, Cild: 1, Marmara Üniversitesi İlahiyat Fakültesi Ktp., kayıt no: 9614, s. 410.

27 Bölgenin o sıralarda askeri harekâtlardaki rolüne dair bkz. 6 Numaralı Mühimme Defteri (972/1564-1565) Özet-Transkripsiyon ve İndeks, II (Ankara: Başbakanlık Devlet Arşivleri Genel Müdürlüğü Yayınları, 1995), s. 218-220.

28 16. yüzyılın ikinci yarısı Avrupa'da oldukça soğuk bir dönemi ifade ediyordu. Randall Nielsen, "Storage and English Government Intervention in Early Modern Grain Markets", The Journal of Economic History, vol. 57, no. 1 (Mar., 1997), s 27. Yine bu dönem Küçük Buzul Çağı diye bilinen aşırı soğuk sürecin içinde bir zaman dilimiydi. Bu dönem en geniş haliyle 1300-1950 yılları olarak tanımlanırken, daha dar haliyle 1570-1900 arası süreci ifade etmektedir. John A. Matthews ve Keith R. Briffa, "The 'Little Ice Age: Re-Evaluation of an Evolving Concept", Geografiska Annaler. Series A, Physical Geography, vol. 87, no. 1, Special Issue: Climate Change and Variability (2005), s. 17. 1580-1610 yılları arası Avrupa'da en sert kış dönemi olduğu iddia edilmektedir. Sam White, The Climate of Rebellion in The Early Modern Ottoman Empire, Cambridge University Press, New York 2011, s. 132. Her ne kadar yılllık periyotlarla sıcaklık ve yağış değerlerine dair niceliksel veriler tutulmamış olsa da incelenen dönemde iklimsel zorlukların Osmanlı üzerindeki etkileri hakkında bkz. a.g.e., s. 136-139.

29 İncelenen dönemde iklimsel zorlukların Osmanlı üzerindeki etkileri hakkında bkz. White, The Climate of Rebellion, s. 136-139.

30 Bunlar kefil bi'l-mal statüsünde mali taahhütlere kefil olan kişilerdir. 
geleneğinin bir yansıması olarak aralarında daha önceden müflis olanlar varsa, kesinlikle buna müsaade edilmeyeceği de belirtilmiştir. Devletin mültezimin iddialarının doğruluğunu sözüne güvenilir kişilerden teyit ettirmesi ${ }^{31}$ hızlı karar verilmesini sağlamış olmalıdır. Çünkü ikna olan resmi makamların ihalenin şimdilik yeniden David mültezime bırakılmasını onaylaması uzun sürmemişti. Dolayısıyla kendisine yeni bir şans tanınmış oluyordu ki bu, herhalde sistemin devamı açısından oldukça etkili bir yöntemdi. Eksiği ve hatası tespit edilen girişimciler bir çırpıda silinip atılmıyordu. Neticede sabık mültezim yeni mali yılda da işine devam ederken, uğradığı zararı telafi edebilmesi için yeni yılın sonuna varmayacak şekilde bir ödeme süresi verilmişti. Mültezimin yanı sıra iltizam şemsiyesi altında gelir elde eden kâtip ya da emin gibi diğer şahıslar da bundan memnun kalmış olmalıdırlar. ${ }^{32}$ Yine sermayedarın yeni süreçte sunduğu kefiller de iltizam kapsamında yerlerini aldılar. David'in zararına bir nevi ortak olan sekiz kişilik ek kefil listesinin tamamı kendi dindaşlarından müteşekkildi ve bunlardan üçü İstanbullu beşi de Selanikliydi. ${ }^{33}$

Bir başka sözleşme metni Bursa ${ }^{34}$ zahire pazarının vergisinin toplanmasını içeriyor. Zaman içerisinde birkaç kez yenilenen iltizam sürecinin belli bir dönemini kapsayan aşağıdaki dökümü sistemin işleyişi ve Yahudi girişimcilerin iktisadi tutum ve durumlarına dair değişik açlardan tarihsel bilgiler yansıtıyor.

31 İmparatorluk resmi hukuk anlayışında şahitlik kurumu bir hayli önemliydi. Bu durum iltizam ihaleleri sürecinde de gözlenebilmektedir. Aleyhte veya lehte tanıklıklar sürecin devamında ya da sonlandırılmasında belirleyici olabiliyordu. Buradaki örneğe ek olarak başkentin salhane, kantar ve pamuk yağı gibi önemli vergilerini içeren iltizama 18 Zilkade 998 (25 Aralık 1580) tarihinden itibaren sahip olan İstanbullu Rafael Yahudi'nin, bu mukataayı kazanmasında eski mültezimlerin göreve devam etmeleri durumunda hazinenin zarar göreceğini divana anlatması etkili olmuştu. BOA, MAD, 3247/9.

32 Emanet usulündeki eminlik ile karıştırılmamalıdır. Buradaki eminler mültezime gelirlerin toplanmasında yardım eden, onun emrindeki kişilerdi. Darling, Revenue-Raising and Legitimacy Tax Collection, s. 130; Çakır, Osmanlı Mukataa Sistemi, s. 122.

33 Selanik’teki kefalet ilişkisi imparatorluğun diğer bölgelerindeki gibi oldukça zengin ilişkileri barındırıyordu. Her ne kadar burada Yahudi girişimci kendi dindaşlarını bulsa da aynı sıralarda pek çok örnekten birinde sipahilerden birinin iltizamındaki tüm kefillerin Yahudi olduğu gözleniyor. Suraiya Faroqhi, "Trade And Revenue Collection In Later Sixteenth-Century Salonica", Oriente Moderno, nuova serie, anno 20 (81), nr. 1, The Ottomans And The Sea (2001), s. 106.

34 İncelenen dönemde kentte Yahudiler' in iltizamlardaki etkin rolü dikkat çekiyor. Gerber, "Jewish Tax-Farmers", s. 147-148. 


\title{
İltizam 2: Hicri 985 (Miladi 1577) Tarihli Bursa Zahire Pazarı Mukataasi ${ }^{35}$
}

Yer: $\quad$ Bursa

Iltizam Konusu: Bursa Zahire Pazar

\section{1. İhale}

\author{
Iltizamın Sahibi: Berekat Yahudi \\ İltizamın Süresi: 985 Cemaziyelevvel gurresinden (17 Temmuz 1577) \\ itibaren 3 ynl \\ İltizamın Tutarı: 7 yük 80 bin akçe
}

\section{2. İhale}

İki yul sonra Bursalı tüccardan Hacı Mehmed ismindeki şahıs devlete başvurarak: "988 Cemaziyelevvelinin gurresinden (14 Haziran 1580) itibaren 50 bin akçe fazlaya yani 8 yük 30 bin akçeye 3 yıllı̆̆ına mukataaya talibim. Hazine-i amireye de 3 yük akçelik kumaş vereceğim” dedi.

Bu arada Yahudinin hesabına bakıldı ve iki senede 2 yük akçelik kesri (zararı) görüldü. Yahudi: "Bir senem kald, buna bir sene daha ekleyin ve tahvilimi yenileyelim, bunun karşılı̆̆ında ben Hacı Mehmed'in ziyade verdiği kısımdan 10 bin akçe daha fazlasın vereceğim, bahsedilen kesri de hazineye teslim edeceğim. Ayruca da hazineye 2 yük akçelik kumaş vermeyince tahvilimi yenilemeyin” diyerek yeni teklif ve taahhütlerini sundu. Bunun üzerine beratı yenilendi

Fakat Berekat, iki senelik kesri vermediği gibi üçüncü sene ile alakası olmasına rağmen mukataasıyla ilgilenmedi. Vermesi gereken kumaşı teslime de maddi gücünün olmadĭ̆g aksine müflis olarak İstanbul'a kaçtı̆̆ı tespit edildi.

35 BOA, D.BRM.d., 24248/2,3, ek3/1-a. 


\section{3. İhale}

Hacı Mehmed yeniden gelerek yine eski tarihten (988 Cemaziyelevveli gurresinden, 14 Haziran 1580) itibaren geçerli olmak üzere aynı süre aynı miktara iltizamı kabul etti. Şart gereğince hazineye verilmesi gereken kumaş bahası 3 yük akçe hazinede hıfz olundu. Mehmed, mukataa ona verilirse 20 bin akçe daha fazla vererek toplamda 3 yıllığına 8 yük 50 bin akçeye teslim edilmesini istedi.

$\mathrm{Bu}$ örneğin temel girdi sahası olan ve "galle pazarı" şeklinde ifade edilen ticaret mahalleri, Osmanlı düzeninde kentlerin en önemli aynî ve nakdî alışveriş mekânlarından biriydi. "Tahıl pazarı" olarak da bilinen bu mekânlar buğday ve arpa benzeri toprak mahsullerinin satıldığı pazar yerleriydi. ${ }^{36}$ Ekin anlamına da gelen galle kelimesine atfen galle pazarı denilen bu satış noktalarına mal getiren ya da oralardan mal götürenlerin ödediği "bac" vergilerini toplama salahiyetini eline alan Berekat' 'n devlet nezdindeki itibarı kendisine bu önemli görevin verilmesini sağlamış olmalıdır. Berekat'ın işleri muhtemelen ilk iki sene iyi gitmesine rağmen, her ihalede olabileceği gibi, süreç içinde Hacı Mehmed isimli bir başka girişimcinin çıkıp yeni tekliflerle mukataaya sonradan talep olması Yahudi işadamının işine engel olmuş gibi görünüyor. Daha sarih bir ifadeyle; Bursalı tacir Hacı Mehmed'in ortaya çıması aslında Berekat' in mukataayı hakkıyla idare edemediğinin görülmesine neden olmuştu. Bundan da ilginci, iki yıl içinde mukataada eksiklik oluştuğunun anlaşılmasına rağmen devlet, hemen Berekat' in elinden iltizamını almadı. Tabii ki normal şartlarda hem daha iyi bir teklif gelmişken, hem de eski sahip işini iyi yürütememişken mukataa ihalesi hemen yeni talibe verilmeliydi. Ancak belki de bir sürpriz gerçekleşmiş ve Yahudi girişimci yeni ve tabii ki daha yüksek teklifle gelince, pek de hoş olmayan siciline rağmen, ihale ikinci kez ona verilmişti. Ne var ki şartlar onun için daha da kötüleşti. Zira bir süre sonra isminin müflis girişimciler arasında geçtiği ve başkente firar etmesi nedeniyle ihalenin ne ona ne de hazineye fayda sağlamadığı anlaşılıyor. Bu durumda devletin yeni talipler araması sürecinde yine Hacı Mehmed'in aday olması neyse ki mukataanın yeniden gelir getiren bir kaleme dönüşmesi adına firsat olmuştu. İhale aşamalarında devletin Yahudi girişimciye gösterdiği müsamaha her halde sistemin ve onu işletme sorumluluğunu üstlenen devletin artı hanesine yazılması

36 Tahsin Özcan, "Pazar", TDV İslâm Ansiklopedisi, 2007, XXXIV, s. 208. 
gereken bir durumdu. Elbette mültezimlerin bir çırpıda etkin cezalarla alaşağı edilmeleri beklenemezdi. Ancak ilk döneminde başarısız bir görüntü çizen bir girişimciye devletin yeniden kredi vermesi herkesin her zaman karşılaşacağı bir durum değildi. Bu küçük örnek imparatorluk iktisadi sisteminin belkemiklerinden olan bir düzenin işleyişi sırasında meydana gelebilecek aksaklıklara karşı teenni ile hareket edildiğini gösteriyor. Belki de bu sabırlı ve affedici tavır, sistemin kurallar iyi işlediğinde neden başarılı olduğunun ve uzun süre devam etmesinin şifrelerini içeren pek çok ayrıntıdan sadece bir tanesiydi.

\section{İltizam 3: Hicri 989 (Miladi 1581) Tarihli İstanbul Pençik Mukataasi ${ }^{37}$}

$\begin{array}{ll}\text { Yer: } & \text { Istanbul } \\ \text { İltizam Konusu: } & \text { İstanbul Pençik Mukataası }\end{array}$

\section{1. İhale}

Iltizamın Sabibi: Rıdvan Çavus,, Cafer ve Mazalto Yahudi

İltizamın Süresi: 989 yalindan itibaren 3 yıl

\section{İhale süreci}

İltizam sözleşmesi devam ederken bir süre sonra ortaklardan Cafer ölmüs, Rıdvan Çavus da mukataa ile ilgisini resmi olarak kesmiştir. Bunu Galata kadisı önünde şabitler de doğrulamı̧ ve tüm mali işlerle Mazalto’nun ilgilendiğini tasdik etmişlerdir. Ilttizam ayrntılarnn içeren kayıtlar da onun elindedir. Mazalto otuz yıldır kimi zaman kâtip ya da kabz-ı mal kimi zaman da mültezim olarak mukataa ile çok yakından ilgilenmektedir. Daha sonra Simovil Yahudi ismindeki birisi muvâzaa yoluyla ona ortak oldu. 992 senesinden itibaren 6 ynl için iltizamı kabul etmişler iken, Simovil'in müflis olması nedeniyle Mazalto onu iltizama dâhil ettirmemiştir. Kendisi 3 sene tek başına sürdürmü̈s, bu süre sonunda eski zarardan başka 20 yük akçeden fazla baki göstermişs sonra ikinci kez ihaleyi elde etmiştir.

37 BOA, MAD, 3247/2,3. 


\section{2. İhale}

Ancak bir sene sonra sürekli zararı ortaya çıkınca eski tahvili kesip yerine yeni tahvil ile dokuz ylllık olmak şartiyla ve yine muvazaa yoluyla, 200 akçe ulufe tayin ettirmek suretiyle Yahudi Simon’u iltizama dâhil ettirmiştir. İki ortak da 989 tarihinden itibaren ortaya çıkan kesirleri dahi kabul ettiler. Bir sene zabt ettikten sonra ortaklarm hesapları görüldüğ̈̈nde, 989-998 arası hesaptan 62 yük akçe baki (kalan borç) gösterdiler. Ancak mukataa Simon'a kalırsa eski yullardan kalan borçları değil kendi zamanının borcunu bile kapatacak gücünün olmadiğg anlaşıldd. Hatta tüccara dabi 40-50 yük borcu vard. Kefillerinden biri de ortada yoktu.

\section{3. İhale}

Bunun üzerine mukataaya yeni talip aranmis ve tüccardan Acemzade Mehmed isminde birisi talip olmuştur. Mehmed mukataanın sürekli el değiştirmesi nedeniyle hesabının karıştığın ve bu nedenle tahsiline dair net verilerin olmadiğın söyleyerek, 998 yılı nevruzundan başlamak üzere, önceki zararlar sahiplerinden emlak, esbab ve kefilleri aracıliğzyla tümüyle tabsil edildikten sonra ve bu zararlar dabil edilmeden 9 ynl için iltizamı kabul ettiğini belirtti. 6 yük peşin ödemeyi kabul ederken kendisine de çavuşluk rütbesinin verilmesini talep etti. Ayrica hüddam ve kâtipleri de kendisinin seçebilmesini şartları arasında sayd. Eğer yeni bir talip çıkarsa ödediği peşin ona geri verilmeden yeni iltizamın verilmemesini de şartlarmın arasina ekledi. Mazalto Yahudinin elinde herhangi bir resmi belgesinin olmadiğın ve sözlü beyanıyla (kavl) kendi zamanlarındaki kesirlerini ödemeyi kabul ettiklerini belirttir. Ödemelerini yaparlarsa ihaleyi alacağını ekledi. 28 Şevval 998 (30 Ağustos 1590) tarihli yazıyla tahvilin Mehmed'e bırakılması kararı verildi.

Uzunca bir mukataa sürecinin yansidiğ bu örnek metin, İstanbul'daki esirlerin satı̧̧ı üzerinden toplanan gelirlerin tahsilini içeren Pençik mukataasına aittir. ${ }^{38}$ Kapsamı daha geniş olduğu anlaşılan bu mukataa içerisinde İstanbul İskelesi'nin

38 Savaşta ele geçirilen esirlerin beşte biri anlamına gelen pençik kelimesi, I. Murad devrinden itibaren devreye sokulan ve esir sahiplerinden her esir başına alınan 25 akçelik vergi için de kullanılmaktadır. Abdülkadir Özcan, "Pençik", TDV İslâm Ansiklopedisi, 2007, XXXIV, s. 226. Bu mukataa 1361'de başlamış olup en eski mali uygulamalardan birisidir. Çakır, Osmanlı Mukataa Sistemi, s. 34. 
gelirlerinin de yer aldığı görülmektedir. ${ }^{39}$ Başkentin hatırı sayılır kalemlerini içinde barındıran bu mukataanın muayyen bir dönemini içeren metin, mültezimlerin bulunması sürecinden başlayarak yıllık periyotlarla mali teftişine ve yeni durumlara göre şartların yeniden belirlenmesine kadar her basamakta titiz bir şekilde yürütülmüştür. Öyle anlaşılıyor ki ihalenin başarıya ulaşmasında hem mültezimler hem de onlara bu fırsatı sağlayan merkezi hükümet için en önemli unsur düzenli ve dürüstçe çalışacak birilerine rast gelmekti. Zira bu örnekte olduğu gibi sürecin bir yerlerinde ortaklardan birinin veya tümünün çeşitli sebeplerle iktisadi girişiminden vazgeçmesi hiç de istenen bir durum değildi. Böyle kasvetli durumlarda devlet, eski mültezimin iyice yıkılmasına firsat vermeden yeniden toparlanmasına vesile olacak şekilde onun yeni ortaklar bulmasına müsaade etmektedir. Herkesin başına aynı şeyler gelmiş midir bilinmez ama burada Mazalto'nun ikinci ortağı da kendisine faydalı olamayınca taşın altına daha fazla elini koyamamış ve iltizamdan vazgeçmiştir.

Bu iltizamın yürütülmesi esnasında bir dönem ortaklık yöntemi olarak muvazaa uygulamasının tercih edilmesi de ilginçtir. İslâm (Osmanlı) hukukunun pek çok ortaklık çeşidi içinde bu usulün tercih edilmesi ayrıca irdelenmeyi hak ediyor. Mazalto' nun sicilinde daha önce zarar ettiğinin yer alması onu bu şekilde biraz hileli bir yöne sevk etmişti. Çünkü kendisine yardım etmek niyetindeki iki arkadaşı da zarar etmekte olan bir iktisadi üniteye sonradan dâhil olmaktaydılar. Halbuki muvazaa yöntemi bir nevi şeri hile idi ve anlaşmaya imza atan iki tarafın aralarında gerçekte var olmayan sahte bir ortaklık kurmaları yöntemini içermekteydi. Dahası Osmanlı hukukunun temel taşlarından birisi olan İslâm hukuku da malların ve işlerin gerçek piyasa değerlerine gitmelerini engelleyerek sonucun sadece kendilerinin menfaatine bağlanarak gayr-1 meşru tutumlara girmeyi ve böylece ihalelere kanunsuzluk karıştırmayı kabul etmemekteydi. ${ }^{40}$ Bu menfi yaklaşıma rağmen her kökenden Osmanlı tebaası muvazaa yöntemini kullanmaya devam etmişler, bundan Mazalto ve ortakları da geri durmamışlardı. Burada Mazalto muhtemelen ihale başkasına gitmesin diye gücü yetmediği halde Simovil ile sahte ortaklık kurmuştu. ${ }^{41}$ Ancak bunlar da işe yaramayacaktı.

39 BOA, MAD, 3247/4.

40 Celal Yeniçeri, İslàm İktisadının Esasları, Şamil Yayınevi, İstanbul 1980, s. 407.

41 Çeşitli misalleri olan bu uygulamanın buradaki örneği "taraflar hiçbir hukuki muamele yapmadıkları ve durumlarında bir değişiklik olmadığı halde bir akit yapmış gibi görünmelerini”" içermektedir. Örnekler için bkz. H. Necati Demirtaş, Açıklamalı Osmanlı Fetvâları, II (İstanbul: Kubbealtı Neşriyat 2012), s. 424-426. 
Zira şerik olmaya çalışanların kedi başlarına bile ayakta duracak mali güçlerinin olmadığı anlaşılmıştı.

Bu ihale sürecinde dikkate değer başka ayrıntılar da yer almaktadır. Devlet iltizamlarla ilgisini azaltan kimselere nereli olduğunu ya da hangi etnisiteden geldiğini umursamadan meritokratik bir tavırla yaklaşmaktadır. Diğer bir ifadeyle sahip olduğu mukataayı yakından takip eden- mesela konu ile alakalı resmi belgelere gözü gibi sahip çıkan- kimseler yine kökenleri ya da inançlarının ne olduğuna bakılmaksızın eşit muameleye tabi tutulmuşlar ve onların bu adımına karşılık resmi makamlar da hatalarını telafi etmeleri için kendilerine yeni şanslar tanımıştır. Yine mukataa süresince ortaya çıkabilecek nahoş durumlarda kefillerin ne kadar önemli olduğu da bu örnekte çok açık bir şekilde görüldü. Söz verdiği halde arkadaşlarını yarı yolda bırakan kefiller aslında mültezimin kaderini de belirlemiş oluyorlardı. Ayrıca eski mültezimlerin arkalarında bıraktığı borçları da yenilerin hiç hazzetmediği ve üstlenmediği meselelerdendi. Yeni müteşebbisler eskilerinin günahını yüklenmeye haklı olarak yanaşmamaktaydılar.

İltizam 4: Hicri 995 (Miladi 1587) Tarihli İstanbul Salhane Mukataası ${ }^{42}$

Yer:

Istanbul

İltizam Konusu: $\quad$ İstanbul Salhane Mukataast

İltizamın Sahipleri: Musa veledi Yagub ${ }^{43}$ ve Elyazar veledi Mohin

İltizamın Süresi: 1 Safer 995'ten (11 Ocak 1587) itibaren 6 yl

İltizamın Tutarı: 26 yük akçe

Aslında İstanbul salhanesi ve ona bağlı birimlerin mukataası, 992 yılının Safer ayının başında (13 Şubat 1584) 6 yıllığına 26 yük akçeye Simon adlı bir Yahudi

42 BOA, D.BŞM.d,00099/ 10.

43 Yagub’un ismi bir sayfada yer almazken (BOA, D.BŞM.d.,00099/10) diğerinde (BOA, D.BŞM.d.,00099/6) zikrediliyor. 
müteşebbise verilmişti. Ancak o, işini yürütemeyip zarar edince yeniden ihaleye çıkılarak mukataa bu sefer 1 Safer 995 tarihinden başlamak üzere 3 yıllık süreyle 13 yük akçeye Rıdvan isminde başka birine verilmişti. İstanbul'da yaşayan Yagub ve Elyazar ismindeki Yahudiler divana başvurarak mukataayı aynı fiyatla ve altı yıl süreyle kendileri almak istediler. Bir önceki mültezim Simon’un kalan zararı için Galata mevacibine 2 yük ve Tershane mühimmatı için 1 yük olmak üzere toplam 3 yük akçe kendi mallarından ödemeyi ve ayrıca 100 bin akçe peşin vermeyi teklif ettiler. Simon'un zararını kapatmak adına ödeyecekleri meblağın karşılığı olarak da 193. bölükden Mehmed Nasır(?) adındaki bir sipahinin dergah-1 ali çavuşluguna terfi ettirilmesini rica ettiler. ${ }^{44}$ Devletin tutumu, hazineye daha fazla gelir getirmesi umudu ve ihtimaliyle yeni tahvilin kabulü yönündeydi ve öyle de oldu.

Bir süre sonra yeni ihale sahiplerinin zararı ortaya çıktığında kefil olmak üzere sipahi oğlanı zümresinden Sefer, İstanbul kadısına bir yazı sunmuş ve ayrıca zarar için 590 bin akçeye kefil olan 26 kişi ile onların müzekkîlerinin (kefillerin kefilleri) isimleri ve mahalleleri gönderilerek kadı tarafından kayıt altına alınmıştır. ${ }^{45}$

Bir ortaklık şeklinde yürütülmeye çalışılan bu ihale örneğinde ise ortakların işe başlarken önceki dönemde ortaya çıkan zararı üstlenmiş olmaları ilginçtir. Bunun için muhtemelen ihaleyle doğrudan ya da dolaylı alakası bulunan devletin işletmelerine (mesela Tersane’ye) ödeme yaptıktan sonra mukataanın gerçek sahibi olacaklardı. Yine iltizam sözleşmelerinin sadece mültezimlere değil başka kişilere de istihdam ya da terfi yolunda destek sağladığının bir örneği de burada görülmektedir. Belki ortakların yakın bir arkadaşı veya kendilerine çeşitli konularda destek çıkan bir tanıdıkları olan Mehmed Sipahi’nin de Dergah-ı Ali çavuşluğuna terfi ettirilmesi şartlar arasına dâhil edilmişti. Bunun ihaleye eklenmesi mültezimlerin dostu olduğu anlaşılan sipahinin hayatında büyük bir değişimi ifade ediyor olmalıydı. Zira Divanı-ı Hümayun çavuşları da denilen bu zümrenin mensupları, o sıralarda oldukça itibarlı kimseler olup padişah dışında kimseye karşı mesul

44 Belgenin buradan sonraki sayfaya (s.11) yansıyan kısmı başka bir kaydın (dellaliye mukataası) devamı olup, değerlendirilmemiştir. Defterin sonradan terkibi sırasında muhtemelen bir sayfa kayması olmuş gibi görünmektedir.

45 BOA, D.BŞM.d.,00099/ 6-7. 
değillerdi ${ }^{46}$ Böylece Yahudi iltizamından bir Müslüman da kendi kişisel yaşamı için kazanç sağlamış oluyordu. Tabi bu karşılıksız değildi ve yukarıda özette ifade edildiği gibi terfinin gerçekleşmesi bahsedilen meblağı sipahinin ödemesi ya da ödenmesine baş kefil olması suretiyle gerçekleşiyordu. Bunların yanında Yahudi ortaklar, imparatorluk geleneğinde hiç de az rastlanmayan bir durum olarak iltizamları dahlindeki uygulamalara dışarıdan yapılacak olası haksız müdahalelere karşı da devlet desteğini arzu ediyorlardı.

Mukataaların rutin ilerleyebilmesi adına vazgeçilmez değere sahip olan kefiller bu iltizamda isimleri ve mahalleleri ile birlikte yer almıslardır. Bu durum tarihsel bilgi açısından bir hayli değerlidir. M. Genç in de ifade ettiği üzere ${ }^{47}$ kefil grubu içerisinde dikkat çeken unsurlardan birisi bu işe soyunanların küçük sermaye grupları niteliğini andıran kimseler olduğudur. Öncelikle kefil ve müzekkilerin yer aldığı bu sistemde tüm kefiller sipahi sınıfından Sefer'in nezaretinde sisteme dahil olmaktaydılar. Onun gözetiminde toplam 590 bin akçeye kefil olan ve ismi zikredilen 26 kefil içinde hacı, bey ve çelebi gibi sıfatları taşıyan kişilere rastlanması mültezimin çevresindeki varlıklı kesimlerin mevcudiyetini haber verir niteliktedir. Az da olsa aralarında sarraf, haffaf, tacir, bezzaz, saraç ve meyhaneci gibi sermaye kaynaklarının neler olabileceğine dair daha ayrıntılı unvanlara sahip olanlar da bulunmaktadır. Kefillerden 23'ünün Müslüman üçünün gayr-i Müslim olması ise bahsedilen ilişki ağının bir başka zenginliğine işaret ediyor. ${ }^{48}$ Yine kefillerin kefilleri için de benzer oranların geçerli olduğu anlaşılıyor. Yahudi girişimcinin ağırlıklı olarak Müslümanlarla kefalet ilişkisi işinde olmasına karşılık, bir tane bile Yahudi kefilinin bulunmaması da dikkat çekicidir. Oysa Müslüman kefil ve müzekkilerin meskûn oldukları mahaller aynı zamanda Yahudi

46 İsmail Hakkı Uzunçarşıllı, Osmanlı Devletinin Saray Teşkilâtı (Ankara: Türk Tarih Kurumu Basımevi, 1988), s. 411.

47 Genç, "İltizam", s. 155.

48 Bir başka mültezim-kefil-müzekki ilişkisi İstanbul salhane ve kantar başta olmak üzere birkaç kalemi içeren mukataaya hükmeden Yahudi Rafael'in listesinden yansıyor. 1 Safer 998 tarihinden itibaren 6 yıl için iltizama talip olan Rafael'in 24 kişilik kefil listesine ek 48 şahıstan mürekkep bir de müzekkiyan grubu vardı. Kefillerden sadece 6 's1 gayr-i müslim iken bunların müzekkileri (12 kişi) de yine gayr-i müslimdi. Rafael'e bu teşebbüsünde destek veren toplam 72 kişi içinde Müslüman arkadaşları sayıca üstün iken, yine Müslümanlar arasında 17 kişinin babasının isminin Abdullah olması da onların sonradan Müslümanlığı seçmiş olabileceklerini akıllara getiriyor. Nihayet mültezime kefalet sözü veren gayr-i müslimlerin tamamının Rum kökenli kişilerden oluşması da ayrıca dikkat çekiyor. BOA, MAD, 3247/12. 
kesimlerinin de yoğun olarak yaşadıkları yerlerdi. ${ }^{49}$ Aşağıdaki haritada görüldüğü üzere, ihaleye mali destek olacak bu kişilerin İstanbul ve Galata'da yoğunlaştıkları görülmektedir. Kefiller ile müzekkilerin bir kısmı aynı mahallede otururlarken bir bölümünün farklı semtlerin farklı mahallelerinde meskûn bulundukları görülüyor. Kefiller ile onlara kefalet edeceklerin de büyük oranda aynı bölgeden olmaları mali ortaklıklarda komşuluk ilişkilerinin başat rolü oynadığını gösteriyor. Birbirlerine kefaletle bağlanan bu sermaye grupları iltizamın sağlıklı işlemesine katkıda bulunurken, aynı ihalede yer alarak iktisadi ilişkilerini daha da geliştirme şansını yakalıyorlardı. Liste içinde Galata’da meskûn Müslüman kefil ve müzekkilerin sayısının hiç de azımsanmayacak oranda görülmesi de ayrıca dikkate değer niteliktedir.

\section{Harita 1: Hicri 995 (Miladi 1587) Tarihli İstanbul Salhane Mukataasının Kefilleri ve Müzekkilerinin Mahalleleri ${ }^{50}$}

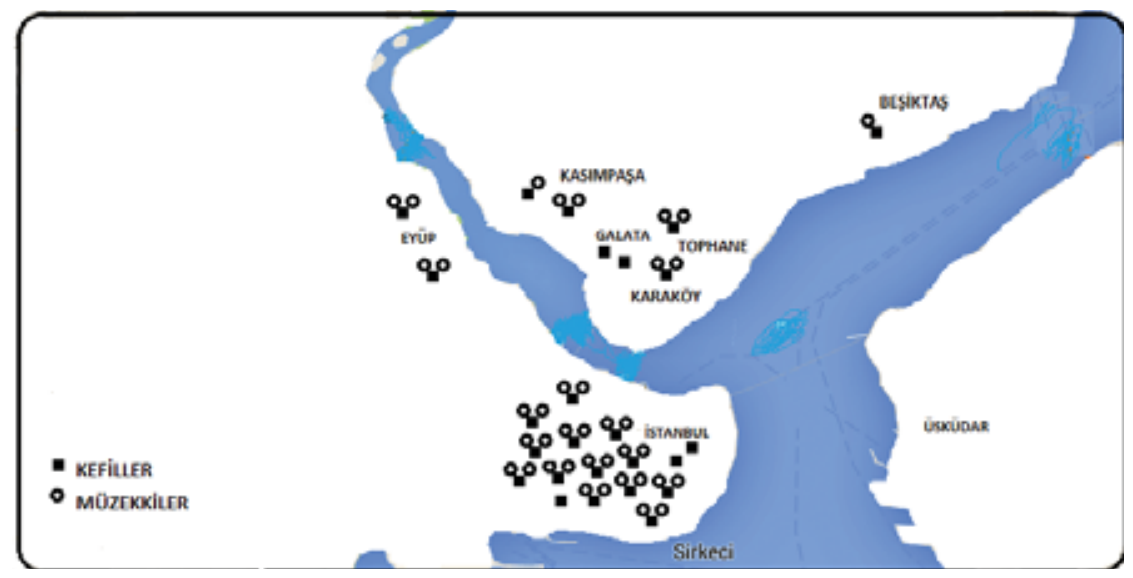

49 Yahudiler' in başkentte yaşadığı mahaller konusunda biraz geç tarihli olsa da krş. Uriel Heyd, "The Jewish Communities of Istanbul in the Seventeenth Century" Oriens, vol. 6, no. 2 (Dec. 31, 1953), s. 309.

50 İsimler için bkz. BOA, D.BŞM.d,.00099/ 6-7. Müzekkilerden, kefilleri ile başka mahallede olanlar ya da mahallesi okunamayanlar eklenmemiştir. 
Buraya kadar incelenen metinlerde Yahudi girişimcilerin kendi dindaşları ve Müslüman arkadaşları arasında sıkı şekilde ortaklıklara giriştikleri ya da kendi iltizamları kapsamında birbirlerine destek oldukları görüldü. Aşağıdaki çok daha teferruatlı kaydedilen bir diğer mukataa metni başka açılardan Yahudiler'in imparatorluk ekonomisindeki yerlerine ve iltizam sisteminin işleyişinin mühim detaylarına işaret ediyor.

\section{İltizam 5: Hicri 1033-1034 (Miladi 1623-1624) Yılı Sakız, İzmir, Çeşme ve Çevresinin Muhtelif Mukataaları ${ }^{51}$}

Yer: Sakız ve Çevresi

İltizamın Sahibi: Elkas Yahudi ${ }^{52}$ ve Sipahi İbrahim

\section{İhale Kapsamı:}

Sakız, İzmir, Çeşme, Balat, Urla, Kuşadası, Eski ve Yeni Foça ve tabi iskeleler gümrük vergileri ve kasabiyeleri.

Sakı'ın ihtisab, harir, milh, elvah, zift, resm-i zemin, iskradanya (?), piyaz, âdet-i ağnam ve Ahikerya (İkeria), İpsara adaları, beytülmâl-1 âmme ve hassa ve cürm-i cinayet ve kasabiyeleri.

Aydın, Saruhan, Karasi, Sakız, Midilli, Sığla, Tuzla, Ezine, Erdek, Bandırma, Kapıdağı, Bozcaada’nın cizye-i yava-i gebran ve kıbtiyân, ispençe, çiftbozan, haymana, beytülmal-1 âmme ve hassa ve mâl-1 gaib ve mal-1 mefkud, bedel-i avârız-1 Ekrad, ${ }^{53}$ rüsum-1 kahve ve kahvehane.

51 İhalenin en geniş kapsamlı tasviri şurada geçiyor: TS.MAD, 2580. 0020/1.

5210 Receb 1033 (28 Nisan 1624) tarihinden itibaren Elkas'in uhdesindedir. 20 Receb 1034 (28 Nisan 1625) tarihinde yani yeni yılın tahvilinde bahsi geçen sipahilere iltizam kapsamındaki birimler dağıtıldı. Ancak mukataa tek kalem olup ayrı ayrı ihale edilemeyeceğinden İbrahim sipahi ile Elkas beraber yeni yılın iltizamını (20 Receb 1034 tarihinden itibaren) üstlendiler. TS.MAD, 2580.0015. Ayrıca mukataayı devletin ihtiyarıla alan diğer sipahiler de haklarından feragat ederek iltizamlarını Elkas'a devrettiler. Aslında İbrahim de "mukataa zabtına vukufum olmadığından” diyerek Elkas’ın mültezimliğini kendi iradesiyle kabul etmiştir. TS.MAD, 2580.0018 .

53 Ekrâd, kelimesi Kürtler’in çoğulu manasında kullanılmakla birlikte Ünal, bu kelimeyi 
Sakı'ın cizye vergisi.

İzmir'de bazı Yahudiler'in cizyesi.

İzmir, Tire, Menteşe, Sakız’n Yahudi ve zimmilerinin cizye-i cevâriyânı (hizmetlerinde olan cariyelerin cizyeleri)

Iltizam Bedeli: Senede 101 yük ve 8443 akçe (Toplam 10.108.443 akçe)

\section{İhale Süreci:}

Istanbul sakinlerinden Elkas ismindeki Yabudi 29 Cemaziyelabir 1032 (30 Nisan 1623) taribinden itibaren 6 ynllı̆̆ına iltizamın sabibi idi. ${ }^{54}$ Ancak bir süre sonra ihalede sorunlar ortaya çıkmaya başladı. Bunun üzerine Elkas divana gelerek şunları söyledi: "Söz konusu mukataanın üzerinden bir sene geçmeden benden alınarak mülazım sipahilere verildiği söylendi; onlar da Salomon, İsak ve Musa Yahudilere feragat etmişlerdir. Yahudiler mukataaya güç yetiremediklerinden birkaç ay sonra benim iltizamıma ortak oldular. Ancak Kaptan Paşa ${ }^{55}$ ve mukataa müfettişi, ismi geçen Yahudiler'in bir senelik tasarruflarında 20 yük akçeyi telef ettiklerini haber verdiler. Ben de tam bu meblağı talep etmek üzere harekete geçecekken yeniden iltizam ayrı kalemler olarak mülazımlara verildi. Fakat bu

konargöçer manasında kullanmıştır. Mehmet Ali Ünal, XVI. Yüzyılda Çemişgezek Sancağı (Ankara: Türk Tarih Kurumu Basımevi, 1999), s. 75. Halaçoğlu da Türkmen, Ekrad ve Kürd kelimelerinin her zaman etnik bir anlam ifade etmediği; bunların konargöçer veya Yörük ile eş anlamlı olarak da kullanıldığı görüşündedir. Yusuf Halaçoğlu "Osmanlı Belgelerine Göre Türk-Etrak, Kürd-Ekrad kelimeleri Üzerine Bir Değerlendirme” Belleten, cilt LX, s. 227 (Ankara, 1996), s. 141, 142. Hatta bazı kayıtlarda "Türkmen Ekradı" ifadesinin geçmesi zikredilen terimlerin her zaman etnik bir anlamı taşımadığını anlatıyor. Aynı eser s. 143. Dolayısıyla her ne kadar ekrâd kelimesi bu iltizamda alakasız gibi görünse de Ekrâd diye anılan zümrenin Türkmenler ya da göçerler olması ihtimali söz konusudur. Bununla beraber Celalî vakaları sırasında göçebelerin (Türkmen, Kürt, Yürük, Çingene ve başkalarının) durmadan yer değiştirmeleri bilinmekte olup bundan Ege çevresi de etkilenmiştir. Mustafa Akdağ, Celalì İsyanları (1560-1603) (Ankara: Ankara Üniversitesi Dil ve Tarih-Coğrafya Fakültesi Yayınları, 1963), s. 67, 123, 213. Dolayısıyla bahsedilen bu Ekrâd gruplarının Celalî sürecinde bölgeye kaçmış olan kesimler olması ihtimali de söz konusudur.

54 TS.MAD, 2580.0019.

55 Kaptan-1 derya olmalı. 
mülazımlardan İzmir İskelesi'nin mukataasını alanlar bana, Sakız İskelesi'ni alanlar sipahi İbrahim'e iltizamlarını feragat yoluyla devrettiler". ${ }^{56}$

Daha sonra Elkas ve İbrahim buradaki mukataa kalemlerinin ${ }^{57}$ tek bir kalem olduğunu ve birbirlerinden ayrılamayacaklarını belirttiler. Bahsi geçen Sakız ve İzmir tevabii mukataalarını 21 Receb 1034 (29 Nisan 1625) tarihinden itibaren ve Sakız gayr-i Müslimlerinin (cizyelerinin) mukataasını ise 1 Ramazan 1033 tarihlinden (17 Haziran 1624) itibaren kendileri yeni ihale kapsamında ortak olarak almak istediklerini divana ilettiler. 3 yılllı̆ına (3x101 yük-8443 akçe= 303 yük 25329 akçeye) iltizamı kabul edeceklerini söylediler. Peşin olarak hazineye 15 yük akçe vermeyi kabul ettiler. Şart olarak da şunları ileri sürdüler: "İltizamın kâtipleri, hademeleri, tercümanı, sakız emini ve iskele nazırı gibi görevlileri bizim istediğimiz kişiler olsun. Sakızdaki "hurde mukataaları" da bizim marifetimiz ile satılsın ve buna kimse mani olmasın. Ayrıca Sakız adası mukataası yine serbestlik ${ }^{58}$ üzerine işletilmeli, vergilerin toplanmasına sandık eminleri müdahil olmasınlar". Ortaklardan İbrahim de sipahilik ulufesinin üç ayda bir teklifteki borcuna karşllık kesilmesini taahhüt etti ve sefere gelmedi diye dirliğinin zarar görmemesi için (elinden alınmaması için) garanti istedi. Aynı durum mukataada istihdam edilen diğer sipahiler için de geçerli olacaktı. Ardından şöyle devam ettiler: "Vergilerin (mal-1 miri) tahsili aşamasında görevlendirilen dilediğimiz 8 kişilik sipahi grubu mukataada istihdam edilerek ulufeleri mukataadan ödenecektir. ${ }^{59}$ İlerleyen zamanlarda daha fazla teklifle veya başka bir yolla mukataa ihalesi başkasına verilirse bizler elinde hakkı bulunan kimseler olduğumuz için ihale yine bize verilsin. Mülazımına (geçici olarak görevlendirilen sipahilere) verilirse düzenli olarak ödensin". ${ }^{60}$

56 TS.MAD, 2580.0019.

57 Sakız ve İzmir tevabii mukataaları. TS.MAD, 2580.0005

58 "Cürm ü cinayet, beytülmal ve bad-1 heva sandık nazırları dahl eylemeyeler" ifadesi ile muhtemelen mukataa kapsamındaki vergi tahsilleri sürecinde rahat hareket etmeleri ve kimsenin resmi konumunu bahane ederek kazançlarına ortak olmaya kalkışmamasını şart koşuyorlardı. Yani vergi toplama konusunda eskisi gibi serbest kalmayı talep ediyorlardı ki bu iltizamın nefes alması için şarttı. Başka bir kayıtta (TS.MAD, 2580.0020/2b) sancakbeylerinin de karışmamasının istenmesi sorunun daha büyük çaplı olabileceğini gösteriyor. Dolayısıyla burada serbestlikten kasıt kadı dışında bir kamu görevlisinin mukataaya karışmamasıydı. Çakır, Osmanlı Mukataa Sistemi, s. 134.

59 TS.MAD, 2580.0005, İbrahim ile ortak.

60 TS.MAD, 2580.0005/Telhis. 
Bir süre sonra mukataa müstakil olarak Elkas'a kaldı ve Elkas şunları ifade etti: "Hem bu iki mukataa aslında tek kalem olduğundan hem de İbrahim mukataayı yürütmeye güç yetiremediğinden o da hakkını bana feragat etti. ${ }^{61}$ Ben de ilk tarihten geçerli olmak üzere 6 yıl 606 yük 13053 akçeye iltizamı kabul ederim. Yeni şartlarım da şunlardır: İltizamdaki kalemler ve Sakız cizyesi birbirinden ayrılmasın ve birinin fazlası diğerinin zararını karşılayabilsin. Sakızlılar her sene 260 sandık sakızı mahzene getirmelidirler, eğer noksan olursa kalan kısmın ücretini versinler. Mukataa dâhilinde tershane-i amireye ödemem gereken para da buradan elde edilecek satışlardan havale olunacak. Ayrıca derya beylerine de salyaneler yine buradan ödenecek. Ancak sakız henüz yetişmediğinden ve tüccarlar sakıza rağbet göstermediğinden dolayı ucuz satışlar yapıldığı için 1032 senesindeki satışlardan normalde sandık başına 12-13'er akçe kazanmak gerekirken, güç bela 10 'ar akçe kazanç sağlanabildi. Ayrıca mukataa arada başkalarına verildiğinden ve Cennetoğlu İzmir'e gelerek külli ihtilale sebep olduğundan 17 yük akçe zarar ortaya çıktı. Eğer yeni tahvil olacaksa daha önce (önceki mültezimler adına) ödediğim zararlar borcuma sayılsın. Fazla ödeme yaptım ise bu fazla kısım bana teslim edilmeden ihale başkasına verilmesin. Yine benden önceki (1030 senesinin mültezimleri) Musa ve Abraham mukataayı 3,5 ay işletmişler, kıstelyevmlerinden daha fazla mal zabt etmelerine rağmen, salyane (derya) beylerine ödemeleri gereken meblağları vermemişlerdi. Ben onların yerine salyane beylerine, ancak borçlanmak suretiyle bir yıllık ödeme yapmıştım. Ellerindeki cizye tahsilâtı ve benim ödememdeki fazla olan kısım kendi borcuma sayılsın" ${ }^{62}$

İltizam mülazımlar tarafından feragatla sadece Elkas uhdesinde devam ederken bir süre sonra Yasif isminde bir kişi ortaya çıkarak iltizamın kendisine verildiğini iddia etti. Buna karşılık Elkas ihalenin kendisinde olduğunu fakat peşin ödemelerinde sıkıntısı bulunduğunu belirtti. Yahudi girişimci Elkas, gerekçeleri ile yeni şartlarını sürerek yeniden talip oldu ve şunları ifade etti: "Bu sene Bağdat civarında ordu görevinde olan mukataa kapsamındaki kullar gelmediler ama yine de gulamiyeleri tahsil edildi. Mukataa geri bana verilirse gulamiyeleri ve peşin ödemelerimi yine tümüyle eda edeceğim. 1035 Şabanı gurresinden (28 Nisan 1626) itibaren Sakız ve çevresinin mukataasını 86 yük 73222 akçeye mukataaya yeniden talibim. Yine Sakızdaki 7511 hanenin $^{63}$ cizyesini de toplayacağım.

61 TS.MAD, 2580.0019.

62 TS.MAD, 2580.0019.

63 Adanın tüm nüfusu 1567 tahririnde ise 8775 hâne idi. Ali Fuat Örenç, "Sakız Adası", TDV İslàm Ansiklopedisi, 2009, XXXVI, s. 8. Elli yıldan fazla süre geçmesine ve Celalî sarsıntılarına rağmen adanın nüfusunun pek fazla değişmediği anlaşılıyor. 
Ayrıca İzmir'deki 75 nefer Yahudi'nin cizyeleri Anadolu Perakendesi Defteri'ne tabi olduğundan haracîler ${ }^{64}$ bunu bahane ederek mukataanın düzenli işleyişine engel oluyorlar. Bu kişilerin cizyeleri Anadolu Perakendesi Defteri'nden alınıp 1035 yllından itibaren bu mukataaya dâhil olacaktır. İzmir şehri, Tire, Manisa ve Sakız Yahudileri'nin ve diğer gayr-i müslimlerin yavalarının (kaçgın) cizyelerinin toplanarak yine İstanbul'da teslim edilmesi usulüyle birlikte 6 yılllğına mukataayı yeniden talep ediyorum. Ancak bazı şartlarım da var: Tunus gemileri Akdeniz'de oldukça fazla gezdiğinden Venedik ve İngiliz tüccar gemileri korkularından gelmiyorlar. Bu nedenle iskeleler işlemiyor ve bu da ihalede zarara neden oluyor. $\mathrm{Bu}$ nedenlerle ortaya çıkan zararımı iki ihale içinde zamanla ödeyeceğim. Bahsedilen 75 Yahudi'nin cizyesini ben toplayayım, buna Anadolu perakendesinin tahsiline memur olanlar müdahale etmesinler. İskelelerdeki görevlileri ben seçeyim, buna da vilayet kadıları karışarak başkalarını görevlendirmesinler. Mukataamın geliriyle Sakız kalesi görevlilerinin de ücretlerini Sakız hurde mukatasından ocaklık olarak tayin edilmek suretiyle ödeyeyim, ancak onlar mukataanın mahsullerinin satışlarına karışmasınlar. Eğer mukataa benim üzerimdeyken daha fazla fiyat veren birilerine ihale edilecek olursa, önceki senelerde ödediğim (diğer mültezimlere ait) zararlar ve gulamiyeler bana geri verilmeden ihale yeni mültezime verilmesin. Tahsilde görevli 5 kişilik sipahi grubunun maaşları mukataadan ödenecek ve bu ödemeler de borcuma mahsup sayılsın. Sakız üreten köylüler de taahhüt ettikleri miktardaki sakızı bana teslim etsinler. Gemi masrafları için sonradan tayin olunan beyler yeni yıl başlamadan masrafların ödenmesini talep etmesinler. Venedik ve İngiliz gemilerine öteden beri arayıcılar konurken şimdi bazıları "elimizde ahitname vardır" diye mani olmaya çalışarak mal kaçırıyorlar. Gemilere bekçi ve arayıcı konulmasına engel olunmasın. Ayrıca mukataalardan biri zarar ederse bu açık, diğerinin kârıyla karşılanabilsin.” ${ }^{65}$

Bu çalışmada kullanılan iltizam metni örneklerinden en hacimlisi olan bu ihalenin süreci, kendi içinde oldukça mühim ayrıntıları içeriyor. Her şeyden önce ağırlıklı olarak vergi toplama üzerine işletilen bu büyük mukataa ciddi değerlere ulaşan mali girdileri ile dikkat çekiyor. Mukataanın Hicri 1032-1035 (Miladi 1623-1626) yıllarında birkaç kez yenilenen tahvillerinde, bir ara tek başına

64 Vergi toplayıcilar.

65 TS.MAD, 2580.0020, 1, 2, 2 b. 
mültezim (emini) olan Elkas aslında İstanbul'da yaşayan bir Osmanlı tebaasıydı. Bu denli fazla sayıda mekânın ve vergi türünün iltizamına sahip olan Elkas, büyük bir iktisadi gelir ünitesinin kontrolünü elinde tutmaktaydı. ${ }^{66}$ Onun iltizamındaki bölgelerin tasvir edildiği aşağıdaki harita bahsedilen genişliği daha net göstermektedir.

\section{Harita 2: Elkas'ın İltizamı Kapsamındaki Yerleşim Birimleri}

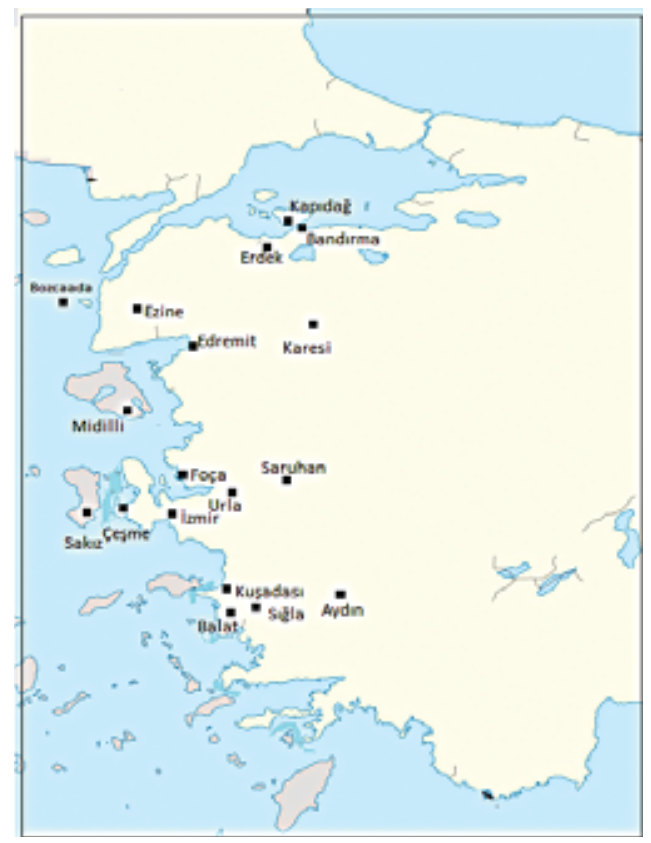

Yahudi Elkas'ın birkaç sene elinde tuttuğu iltizamının kapsamındaki yerlerin aynı zaman da bir gümrük bölgesini ifade eden Ege ve Marmara bölgesinde yer aldığı gözleniyor. ${ }^{67} \mathrm{Bu}$ mukataa, Genç'in "mukataaların içerdiği vergi unsurlarının çeşitliliğiyle kapsadığı mekânın genişliği arasında genellikle ters orantı bulunur”

66 Tabii bundan çok daha büyük mali ve coğrafi iltizamlar tek bir mukataada birleştirilebiliyordu. Mesela II. Mehmed devrinin sonlarında Anadolu ve Rumelideki tüm darphaneler aynı mültezim ortaklığı uhdesindeydi. Sahillioğlu, "Bir Mültezim Zimem Defterine Göre”, s. 149.

67 Gerber'in "coğrafi kolaylıklar vergi toplamada bir avantajken tersi dezavantajdır” şeklinde ifade ettiği durum Elkas için de geçerli olmuş gibidir. "Jewish Tax-Farmers", s. 143. Bu kadar geniş bir bölgeyi arazi şartlarının daha çetin olduğu yerlerde bir ihalede birleştirmek daha zor olmalıydı. 
tezinde vurguladığ ${ }^{68}{ }^{6}$ genel durumun dışında bir örnek olarak sayılabilir. Zira bu mukataa kapsadığı alan kadar özellikle vergi çeşidi (iskele, kasabiye, hurde, ${ }^{69}$ cizye, cürm-ü cinayet, adet-i ağnam vs...) bakımından bir hayli zengindir. Yahudi müteşebbisin, geniş bir coğrafyada, cizye başta olmak üzere birkaç önemli vergi kalemini toplayan iktisadi ünitelerin işleyişini bir süre tek başına idare etmeye çalışması iki yönden önemlidir. Öncelikle devlet bir çatı altında topladığı bu büyük iktisadi yapıyı, en azından bir dönem, bir kişiye ihale ederken sermayedar tebaasına olan güvenini gösteriyordu. Diğer taraftan Elkas'ın hakkındaki daha önceden bir şekilde saraya yansıyan haberlerin idareyi tatmin etmiş olması da söz konusudur. Belki de bu karşılıklı itimadın, söz konusu büyük fiziki ve mali cüsseli iltizamın çeşitli dönemlerde zararla karşılaşmış olsa bile, yine Elkas’ta kalmasına vesile olmuş, üstelik genelde iltizamlar üçer yıllığına verilirken burada altışar yıllık anlaşmalara imza atılmıştır. Ancak siyasi ve askeri kaygılar devreye girdiğinde, devlet mekanizmasının, bazen mali darlıklarla karşı karşıya kalan bu ihaleyi adeta kamulaştırır gibi kendisine bağlı sipahilere devretmesi de bahsedilen güven ilişkilerinin devlet çıkarı ağır bastı̆̆ında askıya alınabileceğini işaret ediyordu. ${ }^{70}$

Mukataaların yürütülebilmesi için belli bir seviyede sermayenin gerekli olduğu hususu bu misalde bir kez daha görüldü. Böylesi büyük iltizamlarda süreci kazançla kapatmak isteyenler için bu çok daha elzemdi. Elkas'ın, ihaleye kimi dönemlerde ortak olan Yahudi dindaşları ya da mülazım sipahilerin başarısızlıkları neticesinde tek başına mukataayı üstlenmesi, hatta bunu eski mültezimlerin zararlarını kapatarak kabullenmesi, daha çok onun mali gücüyle alakalı olmalıydı. Devletin müdahalesine rağmen sipahilerin ve bir süre işi yüklenmeye kalkışan birkaç Yahudi'nin, mültezimlik haklarını kendi istekleriyle en sonunda Elkas'a devretmelerinin sebebi de herhalde buydu.

İltizam düzeni gereği ihalelere talip olan girişimcilerin şartlarını dikkate alan resmi makamlar, Elkas'ın (ve ortaklarının) da ilginç talepleriyle karşılaşıılar. Yahudi müteşebbisin isteklerinin başında görevi süresince kimsenin dışarıdan haksız

68 Mehmet Genç, "Mukâtaa", TDV İslàm Ansiklopedisi, 2006, XXXI, s. 129. Burada incelenen model Genç'in "çan eğrisi modeli” ni andırmaktadır.

69 Hurda mukataa ayrı cinsten olan ve düşük gelirli mukataalar için kullanılan bir tabirdi. Tayyip Gökbilgin,’XVI. Asırda Mukâtaa ve İltizam İşlerinde Kadılık Müessesesinin Rolü”, IV. Türk Tarih Kongresi Zabutları (1952), s. 437.

70 Kanuni döneminde kapıkulu sipahilerinden kıdemlileri padişahın özel koruması görevini yürütürlerdi ve sefer sonunda mülazım yazılmak suretiyle mukataaların bir yılllk yönetiminde, vergilerin toplanmasnda istihdam edilirlerdi. Çakır, Osmanlı Mukataa Sistemi, s. 45. 
müdahale yapmasına müsaade edilmemesi geliyordu. Elkas'in bu tip araya girmelerin önlenmesini rica etmesi boşuna değildir. Uygunsuz vergi talepleri ile birlikte başka türlü yollarla rahatsızlık vermeleri olası kişiler arasında sancakbeyleri ve eminlerin isimlerinin anılması mültezimin gücünün yetmeyeceği huzursuzluk kaynağı olabilecek makamları işaret ediyordu. Muhtemelen bu nedenle Yahudi müteşebbis ısrarla, "serbestlik” üzerine mukataayı işletmek istiyordu. Elkas'ın diğer sözleri arasında çalışacağı ekibini kendisinin seçmesini şart koşması her şeyden önce kendi rahatı içindi. ${ }^{71}$ Devletin de mukataanın dolayısıyla ödemelerin düzenli sürdürülmesi adına buna ses çıkarması beklenemezdi. Yine iskele gelirleri açısından o sıralarda Akdeniz'in güvenliğini tehdit eden Tunus (korsan) gemilerinin yabancı tüccarları rahat bırakmasının istenmesi de yabana atılır bir durum değildir. ${ }^{72}$ Bu ciddi tehdit neticesinde Venedik ve İngiliz gemilerinin bölgeye pek fazla uğramaması mukataa kalemlerinden birinin, hem de önemli birinin akamete uğraması anlamına geliyordu. Yine kaçakçılığın engellenmesi açısından tartışılmaz öneme sahip olan ve gemilerdeki malları teftiş eden "arayıcı" ismindeki görevlilerin de işlerine devam edebilmesinin istendiği görülüyor. Bu ifade denize düşen nesneleri arayıp çıkaran ya da gümrük kontrol memurluğu gibi işlevleri yerine getirenleri niteliyordu. Herhalde Elkas mültezimin burada israrla üzerinde durduğu kişiler bu sonuncusu olan ve gemi denetiminde sorumluluğu bulunan şahıslardı. ${ }^{73}$

71 Yahudi cemaati üyelerinin iltizam almaları durumunda kendi dindaşlarını iş arkadaşları olarak seçmeleri pek şaşırtıcı olmasa gerekir. Aynen Hicri 1016 (Miladi 1607-1608) yılında İzmir ve Sakız iskelesi iltizamını yürüten Avrahim veled-i David'in vekili ve kâtibi olarak kendi çevresinden birilerini tercih ettiği gibi. TS.MAD, 7290.0009 .

72 Garp Ocakları teşkilatı bünyesinde faaliyet gösteren bu gemiciler korsanlık faaliyetlerine bulaşarak diğer Avrupalı gemilerin geliş gidişlerini sekteye uğratıyorlardı. Zira bilindiği üzere Kuzey Afrika'da bulunan Cezayir, Tunus ve Trablusgarp Ocakları'nın en önemli gelir kaynakları korsanlık faaliyetleriydi. Onlar Akdeniz'de kıyısı olan ve burada ticaret yapan pek çok ülkenin gemilerini zapt edip mallarına el koyuyorlardı. Serhat Kuzucu, "XVIII. Yüzyılda Uluslararası Bir Sorun Olarak Garp Ocakları'nın Akdenizdeki Korsanlık Faaliyetleri”, Gazi Akademik Bakı̧s, c. 9, sayı 17 (Kış 2015), s. 173. O sıralarda, imparatorluk divanının Tunus’ta "Dayı"lar kontrolündeki büyük gemi filolarıyla yapılan korsanlıkları önleme çabalarına dair bkz. Jamil M. Abun-Nasr, "The Beylicate in Seventeenth-Century Tunisia", International Journal of Middle East Studies, vol. 6, no. 1 (1975) (Cambridge: Cambridge University Press), s. 75.

73 İltizamı Hicri 1039 (Miladi 1629-1630) yılında alan Musa Yahudi de aynı konuda istekte bulunmuş, hatta onlara ek olarak bekçilerin de ticaret gemilerinde istihdam edilmelerini şart koşmuştu. TS. MAD, 4183/2. 
İleri sürdüğü şartlar ve kullandığı dile bakıldığında sisteme hâkimiyeti görülen girişimci Elkas'ın mukataanın işleyişine dair ayrıca teknik talepleri vardı. Zeki girişimci önemli gelir kalemlerinden olan sakızın temini için üretici köylülerden alması gereken mahsulleri zamanında ve miktarınca tahsil edebilmeyi istemekteydi. Eğer köylüler aynî ödemede sıkıntı yaşayacaksa bunun karşılığı olmak üzere nakdî ödeme yapmalıydılar. Ancak Elkas' in hiç arzu etmediği şekilde, tacirler arasında sakıza olan talep düşmekle birlikte Cennetoğlu isyanının ${ }^{74}$ mukataa bölgesindeki iklimi de olumsuz etkilemesi sonucunda fiyatlarda inişler yaşanmış ve sakız konusunda 17 yük (17.000.000) akçelik ziyan yaşanmıştı. ${ }^{75}$ Aslında Elkas' in ihale sürecinde zararla karşılaşması ilk de değildi. Daha önceki Yahudi mültezimler Musa ve Abraham'ın da zararlarını kendisi ödemişti. Elkas, bu zararlarının yeni bir ihale sürecine işaret ettiğinin farkındaydı ama yeni dönemde kendisinden önceki mültezim dindaşları adına ödediği salyanelerin bu zararlarına sayılmasını isteyerek mukataadan vazgeçmek istemiyordu. Böylece mukataanın denizcilikle alakalı kısmında Elkas, sözleşme kapsamında derya beylerine daha önce ödenmesi gereken, ancak kendisi tarafından karşılanan ücretlerin (salyanelerin) ${ }^{76}$ içinde fazlalık varsa bunun da borcuna karşılık sayılmasını talepleri arasında sıralamışı.

Yahudi müteşebbis, 1626 yılında daha fazla fiyat teklifiyle (86 yük 73222 akçe) ihaleye yeniden talip olduğunda yeni şartlar öne sürerken ne yazık ki yine yaşadığı talihsizlikler nedeniyle ortaya çıkan zararlarını konu etmişti. Mukataanın hatırı sayılır girdilerinden olan iskele gelirlerinin düşmesi meselesinde Akdeniz'de dolaşan Tunus gemileri nedeniyle Venedik ve İngiliz tacirlerin bölgeye uğramamasını ileri sürmüştü. Böylece iyi gelir getirecek kaynak gruplarından mahrum kalmış ve mukataanın hesapları yine istenilen seviyede gerçekleşmemişti. Buradaki

74 Balıkesir çevresinde başıbozuk kuvvetlerle isyan bayrağı açan ve Manisa ile Aydın taraflarını istilâ eden Cennetoğlu bir süre bölgede huzursuzluk kaynağı olmuş, 1624 yılında Manisa’da öldürülmüştür. Mücteba İlgürel, “Anadolu (Anadolu İsyanları)”, TDV İslâm Ansiklopedisi, 1991, III, s. 119.

75 Sakız adasındaki sakız üretimi üzerine bir monografik çalışma yapan Emecen’e göre adanın Osmanlılara geçişinden hemen sonra yapılan tahrir ile 1634 yılında yapılan tahrir arasında en azından üretici köylülerin sayısı bakımından cüzi bir gerileme olmuştur. Feridun Emecen, "Sakız Adasının Sakızları: Küçük Bir Osmanlı Tarım İşletmesi”, Osmanlı Araştırmaları, c. 37 (2011), s. 5. Dolayısıyla Yahudi sermayedarın yaşadığı bu sıkıntı o yılla alakalı geçici bir sorun gibi görünmektedir.

76 Çeşitli mukataa gelirlerinden, derya beyleri adı verilen ve savaşlarda donanmada görev alan beylere ücret ödenmesi bilindik bir uygulamaydı. Örnek ve ayrıntılar için bkz. İdris Bostan, "Salyane", TDV İslâm Ansiklopedisi, 2009, XXXVI, s. 59. 
zararlarını da tek kalemde birleştirilecek olan ihalede ödemeyi teklif ediyordu. Yine Yahudi sermayedar, İzmir'deki dindaşlarının cizyesini toplamayı ve Anadolu Perakende Defteri'ni tutan tahsildarların ona karışmamasını istemişti. Burada "perakende" diye ifade edilen tabir ana cemaatinden ayrı düşmüş topluluklar için kullanılmaktayd ${ }^{77}$ ve Elkas, cizyesini toplamak istediği 75 kişilik Yahudi cemaatinin Anadolu Defterleri'nde kayıtlanmamasını talep ederken vergilerini bağımsız olarak kendisi tahsil etmek niyetindeydi. Elkas, ihalenin geniş ödeme üniteleri içinde Sakız Kalesi görevlilerinin (neferâtının) maaşlarının da adanın burde mukataasının gelirlerinin ocaklık suretiyle düzenlenerek ödenmesini istiyordu. Zaten genelde kale muhafızlarının maaşları ocaklık suretinde ödenmekteydi. ${ }^{78}$ Burada ilginç olan mukataa içinde bir birimin bu statüde düzenlenmesidir. ${ }^{79}$ Hurde mukataası denilen düşük gelirli mukataa, ocaklık suretine bürünerek hem söz konusu ünitenin mahsulâtının toplanması esnasında dışarıdan müdahaleler önlenecek hem de devlet söz konusu üniteyi kendi iradesi ve iktidarı ile daha yakından kontrol etme şansını yakalamış olacaktı. Bu arada Sakız Kalesi'nin müstahdemlerinin de iaşelerinin aynı mukataanın gelirinden sağlanması ihalenin coğrafî zenginliği yanında istihdama sağladığı katkının da aynı oranda çeşitliliğine işaret ediyor. Bu militarizm-iltizam ilişkisi tarihçiler arasında tımar düzeni-askeri düzen arasındaki ilişkinin gördüğü ilgiden uzak kalmıştır. Belki tımardaki kadar güçlü değil ama yine de iltizam düzeni ile askeri yapının özellikle taşrada desteklendiğini daha fazla dile getirmek gerekiyor. ${ }^{80}$

77 Emine Erdoğan, “Ankara Yörükleri (1463, 1523/30 ve 1571 Tahrirlerine Göre)”, OTAM (Ankara Üniversitesi Osmanlı Tarihi Araștırma ve Uygulama Merkezi Dergisi), sayı 18 (2005), s. 125.

78 Çakır, Osmanlı Mukataa Sistemi, s. 91.

79 Birden fazla uygulamayı içeren ocaklık sistemi içindeki yöntemlerden biri de belli bölgelerin gelirlerinin saraya bağlı bazı birimlerdeki görevlilerin maaşlarına karşıllı kendilerine tahsis edilmesiydi. Orhan Kılıç, "Ocaklık", TDV İslâm Ansiklopedisi, 2007, XXXIII, s. 317. Bu yönüyle iltizam sistemi ile oldukça benzeşen ocaklık uygulamasının mukataa düzeni içindeki yeri yeni araştırmaların ilgisini bekliyor. Bu anlamda ocaklık düzeninin gelişmesinin iltizamların da yaygınlaşmasını sağladığı görüşü de değerlendirilmeye açıktır. Pál Fodor, "Fur of Lynx and Arable Land: The Wealth of an Ottoman Tax Farmer in the Early Seventeenth Century", Oriens, vol. 37 (2009), s. 191. Fodor böyle bir genel kanı olduğunu ancak Macaristan örneğinden hareketle özellikle 17. yüzyılın ikinci yarısından sonra artan düzeyde ocaklıkların, iltizamların yerine ikame edildiğini savunuyor. Pál Fodor, "Some Notes On Ottoman Tax Farming In Hungary”, Acta Orientalia, Academiae Scientiarum Hungaricae, vol. 54, no. 4 (2001), s. 433.

80 Sakız’n daha önceki süreçte yine Yahudi müteşebbislerce elde edilen mukataalarında kale görevlilerinin iltizam kapsamındaki ödemelerinin düzenli seyretmesi ve bu hususta devletin ince 
Bu arada ilk ihale sonrasında Elkas ile İbrahim'in şartnamenin sonuna ekledikleri şartlar da ilginç bir duruma işaret ediyor. Normalde ihale sürecinin herhangi bir zamanında yüksek teklif veren birilerinin ihalenin yeni sahibi olması ya da olmaları mümkün iken ${ }^{81}$ burada sürpriz taliplerin mukataayı almak için harekete geçtiklerinde bunun engellenmesini talep etmeleri dikkate şayandır. Ortak girişimciler, bahsedilen ihtimaller dâhilinde ortaya çıkarak iltizama müdahil olmak isteyenlere karşı, kendilerinin hak sahibi (zevilyed) olduklarını belirterek tahvillerin eskisi gibi kendileriyle yenilenmesini istiyorlardı. Yine bu ihale metinleri göstermektedir ki birilerinin kendi nüfuzlarına güvenerek iltizam süreçlerine yasadışı müdahale etmeleri de o kadar kolay değildi. Yasif isimli Yahudi örneğindeki gibi, ellerinde nereden alındığı net bir şekilde belli olmayan, belki de sahte belgelerle mukataaların işleyişine karışmak isteyenler her zaman emellerine ulaşamıyorlardı. Hatta Yasif' in bunun için adamlarından birini müdahil olarak göndermesi dahi işine yaramamışt1. ${ }^{82}$

Mukataa sistemi içerisinde mültezimler listenin başında olmak üzere pek çok kişinin doğrudan ya da dolaylı olarak istihdam edildiği görülüyor. Elbette müstahdem gruplar iltizamların içeriğine bağlı olarak değişecektir. Burada son örnekteki metinlere yansıdığı üzere müfettişler, kâtipler, sandık eminleri, sakız emini, iskele nazırı, tercüman, bekçiler, arayıcılar, simsarbaşı, hademeler ve nihayet vergi tahsilinde görevli kapıkulu sipahileri, Elkas Yahudi'nin geniş mukataasında hayatlarını kazanan ve onun seçtiği gruplardan sadece bir kısmıydı. ${ }^{83}$ Bunlar içeri-

eleyip sık dokuması dikkate şayandır. Adanın iskele gümrüğünün iltizamını Hicri 1015 (Miladi 1606-1607) yllında elinde bulunduran Avrahim (Abraham) veled-i David Orahim ismindeki Yahudi mültezime bu konuda sıklıkla hatıllatmalar ve teftişler yapılmaktaydı. Zira Sakız Kalesi'ndeki mustahfiz ve topçulardan oluşan 238 kişinin ödemeleri (mevacipleri) onun iltizamı kapsamında peşin olarak yapılıyor, sonra hesabından düşülüyordu. TS.MAD., 7290.0026. Belki iltizam sahiplerinin çok da hoşuna gitmeyecek derecede onları denetleme telaşında olan idarecilerin bu tavrı iki stratejik konunun bir arada değerlendirilmesi neticesinde pek de şaşılacak bir durum değildir. Bu arada yine aynı iltizam kapsamında resmi görevle yola çıkan gemilerin yağlanma ihtiyaçları olduğunda mültezimin yağ tedarikinden sorumlu tutulması da iltizam ile devletin askeri-stratejik planlarının örtüştüğü ve az dile getirilen, başıı başına ayrı bir araştırma konusu olan hususlardan biri olarak sayılabilir. TS.MAD., 7290.0002.

81 Genç, "İltizam", s. 155.

82 TS.MAD, 2580.0021.

83 Yahudi müteşebbisin Sakız ve İzmir İskeleleri’yle ilgilenecek kadının dahi kendi dilediği kişi olmasını istemesi ilginçtir. TS.MAD, 2580.0020/2. Burada Elkas'ın bahsettiği bölgedeki iki kadıdan hangisinin ilgileneceğini en azından kendisinin seçmesine müsaade edilmesini talep etmiş olması gerekir. Böylece bir görevi de mukataa müfettişliği olan kadının tanıdık birisi olmasını 
sinde sipahilerin özel bir konumu olduğunu ifade etmek gerekir. Nitekim devlet ihale sürecinde mukataayı kendi görevlileri olan sipahilerin idaresine alırken bir nevi el koymuş oluyordu. Bu duruma Yahudi girişimcinin ses çıkar(a)madığı anlaşılıyor. Bahsedilen yılların (1623-1626) imparatorluğun oldukça buhranlı bir sürecine denk gelmesi bu el koymanın onunla alakalı bir durum olabileceğini akla getiriyor. O yıllar Sultan II. Osman'ın katlinin yankılarının henüz devam ettiği, Anadolu’da Abaza Mehmet Paşa isyanının etkili olduğu, İran'ın Bağdat'ı geri aldığı ve Safevilerle uzun savaşlar döneminin yaşandığı yıllardı. Dolayısıyla sefer süreçlerinde yaşanan devletleştirme işlemlerinden birine Elkas da uğramış olabilir. Ancak bahsedilen "atanmış" mültezimlerin (eminlerin) mukataayı idare etmeye güç yetirememeleri yeniden Yahudi sermayedarın mültezimlik yolunu açmıştır. Aslında bu sipahilerin mültezim olmak gibi bir arzularının da olmadığı söylenebilir. Zira ihale şartları içinde kendi ulufelerinin ödenmesi ve sefere gitmeme durumunda gelirlerine el konulmamasını rica etmeleri bunu gösteriyor. Bu durumda öyle anlaşılıyor ki Yahudi girişimci onların ortağı değil hamisi rolündeydi. Nihayet mukataanın bir kısmında zarar oluştuğunda bu açığın diğer kalemlerle kapatılmasını istemesi de önceki örneklerle uyuşan akıllıca bir başka talepti. ${ }^{84}$

\section{Sonuç}

Osmanlı tarihçilerinin çok fazla ilgisini çekmediğinden ya da ayrıntılarla uğraşmak gerekli görülmediğinden olsa gerek iltizam sözleşmelerinin metinleri pek nadir surette irdelenmiştir. Burada 1560-1630 yıllarına tarihlenen ve Yahudi kökenli Osmanlıların mültezim unvanını taşıdığı beş iltizamın ihale süreci, bu süreçlerin öncesi ve sonrası gelişmeleri ile birlikte, bahsedilen metinler üzerinden değerlendirilerek, iltizam sistemi ve Yahudiler’in rolü konusuna katkıda bulunulmaya çalışılmıştır.

Metni incelenen sözleşmelerden anlaşıldığ 1 kadarıyla, her şeyden önce Osmanlı Yahudisi olan sermayedarların mukataa sistemine yoğun bir ilgisinin olduğu görülmüş ve resmi makamların da iltizamları hak eden taliplerine, kökenlerine bakmaksızın çekinmeden vermek gibi bir tavır içinde bulundukları anlaşılmıştır. Hem coğrafi hem de mali yönden büyük sayılabilecek mukataaların kimi

istemiştir. Kadıların mukataalardaki rollerine dair bkz. Gökbilgin,’XVI. Asırda Mukâtaa ve İltizam İşlerinde Kadılık Müessesesinin Rolü”, s. 436-437.

84 Bu uygulama mukataalarda sık görülürdü. Çakır, Osmanlı Mukataa Sistemi”, s. 3, 116. 
zamanlarda tek bir girişimciye devredilmesi her iki tarafın karşlıklı güveninin bir işareti olarak değerlendirilebilir. Devlet, mukataasının işlemesi sürecinde mali açından Yahudi tebaasına güven beslerken, Yahudi girişimciler de devletin koruması altında çalışabileceklerini gösteriyorlardı. Bu güven sadece sivil ve resmi taraflar arasında değil sivil kesimler arasında da gözlenmiştir. Yahudi müteşebbislerin zor zamanlarında kendisilerine destekçi olacak kefiller veya müzekkiler ararken, Müslüman tebaadaşlarının kapısını çalmaktan çekinmedikleri tespit edilmiştir. Aynı rahatlığın onların kefalet teklifini kabul eden Müslüman iş arkadaşlarında da bulunduğu söylenebilir.

Çalışma içerisinde mukataa sistemine yön veren mültezimlerin çeşitli şartlar ileri sürerken kendilerinden önceki zararları hassasiyetle konu edindikleri de görüldü. Herkes "benden önceki zararları/borçları öderim ama..." diye söze başlarken, bu teslimatlarına karşılık gelecekteki ödemelerinin ederi kadar kısmından muaf olabilmeyi istiyordu. Bunun yanında yine mültezimleri en çok ilgilendiren konulardan birinin işletmeleri süresince çalışacakları "iş arkadaşlarını", hatta onları denetleyecek kişileri kendi istedikleri kimselerden seçebilmek olduğu da iddia edilebilir. Eğer köylülerle ödeme konusunda sıkıntı yaşarlarsa bu buhranlı dönemlerde de devletin nefesini en yakınlarında hissetmek arzusunda gibiydiler. Savaşlar gibi beşeri, aşırı soğuklar gibi doğal gelişmelerden iktisadi üniteleri etkilendiğinde oluşacak zararlarının da, affedilmese bile en azından telafisi sürecinde daha uzun vadeler talep ediyorlard.

İltizam sözleşmeleri metinleri gösterdi ki hemen her mukataa süreci beklenmedik problemlere gebe olmaya adaydır. Ancak sermaye ve işleyiş konusunda çeşitli dönemlerde sıkıntılar yaşayan Yahudi müteşebbislerin önleri hemen kesilmediği de incelenen metinlere yansımıştır. Onların ısrarla yeni teklifler sunarak masaya oturduklarında, daha önceki başarısızlıklarının bahane edilmeyerek tekliflerinin her zaman geri çevrilmediği de iddia edilebilir. Bu noktada sermayesi ve nüfuzu güçlü mültezim adaylarının bulunması güçlüğünü göz ardı etmeyen devletin eski ve haklarında bazı olumsuz haberler gelen talipleri kaçırmamak istediği gözlendi. Araya girerek iftiralarla ya da sahte belgelerle aksayan iltizamları ellerine geçirmek isteyenlere ise imparatorluğun bilindik ve oldukça güçlü "diplomatika” geleneğinin izin vermediği eklenebilir. Bazen yeni taliplerin durumları yerel şahitlerden ve mevcut kayıtlardan incelendikten sonra kararların alınmaya çalışıldığı ve böylece yeni mültezimlerin atamasının yapıldığı anlaşılmaktadır. Bütün bunların neticesinde, yüzlercesi başka meseleleri aydınlatmaya yardımcı 
olmak üzere bekleyen iltizam sözleşmelerinin sınırlı sayıdaki örneği bile sistemin işleyişine daha içerilerden bakmayı temin etti.

Osmanl İltizam Sözleşmelerine Yansıyan Yönleriyle Yahudi Girişimciler (1560-1630) (7 Belge ile Birlikte)

Öz — Osmanlı İmparatorluğu’nun zengin tebaa mozaiğinde farklı etnik ya da dini kökene sahip pek çok zümre yer almaktaydı. Bunlardan biri olan Yahudiler, merkezi hükümetin kendilerine verdiği fırsatları en iyi şekilde değerlendirirken, büyük devletin iktisat düzenine finansal ve üretimsel alanlarda ciddi katkılarda bulundular. Onların özellikle sermayedar rolleri on altıncı ve on yedinci yüzyıllarda iltizam ihalelerinde sıklıkla yer almalarına destek oldu. Gerek kendi dindaşları gerekse Müslüman tebaadaşları ile birlikte birçok iltizam ihalesinde yer alan Yahudiler bazı iktisadi ve hukuki zorluklarla karşılaştılar veya kendileri iltizam süreçlerinde problem kaynağ oldular. Bu sıkıntılı dönemlerde mümkün olduğu kadar üretim ekonomisi içinde kalmaları yönünde bir resmi tavırla karşılaştılar. Devletin Yahudi girişimcilere ellerindeki nakit sermaye nedeniyle ihtiyaç duyarken, bahsedilen grupların da iltizam sözleşmelerinde ısrarla yer almaya devam ettikleri anlaşılıyor. Her iki tarafın da sistemin devamının kendileri açısından faydalı olacağına inandığı ve iltizam sözleşmelerinin feshedilmesinin son çare olarak düşünüldüğü de söylenebilir. Ayrıca bu çalışmada incelenen iltizam sözleşme metinleri, mali zorluklara düşen Yahudi mültezimlerin devlet tarafından nasıl korunduklarına dair ilginç ayrıntıların da ortaya çıkmasına yardımcı olmuştur.

Anahtar kelimeler: Osmanlı, Yahudi, iltizam, mukataa, mültezim 


\section{EKLER:}

\section{Tablo: İncelenen İlizam Metinlerinin Sahipleri ve İltizamları}

\begin{tabular}{|c|c|c|c|}
\hline Mültezimin İsmi & İltizam Konusu & İltizam Süresi & Kaynak \\
\hline $\begin{array}{l}\text { David veledi Avahim } \\
\text { Yahudi }\end{array}$ & Selanik Gümrüğü & $\begin{array}{l}11 \text { Ramazan } \\
973 \text { ten } 3 \text { yil }\end{array}$ & $\begin{array}{l}\text { BOA, } \\
\text { D.İSM.d.25364/2 }\end{array}$ \\
\hline Berekat Yahudi & $\begin{array}{l}\text { Bursa Zahire Pazarı } \\
\text { Bacı Mukataası }\end{array}$ & $\begin{array}{l}985 \mathrm{C} \text {. evvel } \\
\text { gurresinden } \\
\text { itibaren } 3 \text { y1l }\end{array}$ & $\begin{array}{l}\text { BOA, } \\
\text { B.BRM.d.24248/2 }\end{array}$ \\
\hline $\begin{array}{l}\text { Rıdvan Çavuş, Cafer } \\
\text { ve Mazalto Yahudi }\end{array}$ & $\begin{array}{l}\text { İstanbul Pençik } \\
\text { Mukataası }\end{array}$ & $\begin{array}{l}989 \text { yılından } \\
\text { itibaren } 3 \text { yıl }\end{array}$ & $\begin{array}{l}\text { BOA, MAD, } \\
3247 / 2,3\end{array}$ \\
\hline $\begin{array}{l}\text { Musa veledi Yagub ve } \\
\text { Elyazir veledi Mohin }\end{array}$ & $\begin{array}{l}\text { İstanbul Salhane } \\
\text { Mukataaası }\end{array}$ & $\begin{array}{l}1 \text { Safer } 995 \text { 'ten } \\
\text { itibaren } 6 \text { yil }\end{array}$ & $\begin{array}{l}\text { BOA, D. } \\
\text { BŞM.d.00099/6 }\end{array}$ \\
\hline Elkas Yahudi & $\begin{array}{l}\text { Sakı, İzmir, Çeşme } \\
\text { ve çevresinin cizye } \\
\text { mukataası }\end{array}$ & $1035 \mathrm{y}_{1} \mathrm{l}_{1}$ & TS.MAD, 2580.0005 \\
\hline
\end{tabular}




\title{
2. İltizam 5, Hicri 1033-1034 (Miladi 1623-1624) Yılı Sakız, İzmir,
} Çeşme ve Çevresinin Muhtelif Mukataalarına Ait Belgeler

\author{
Belge 1: TS.MAD, 02580. 0005.00
}

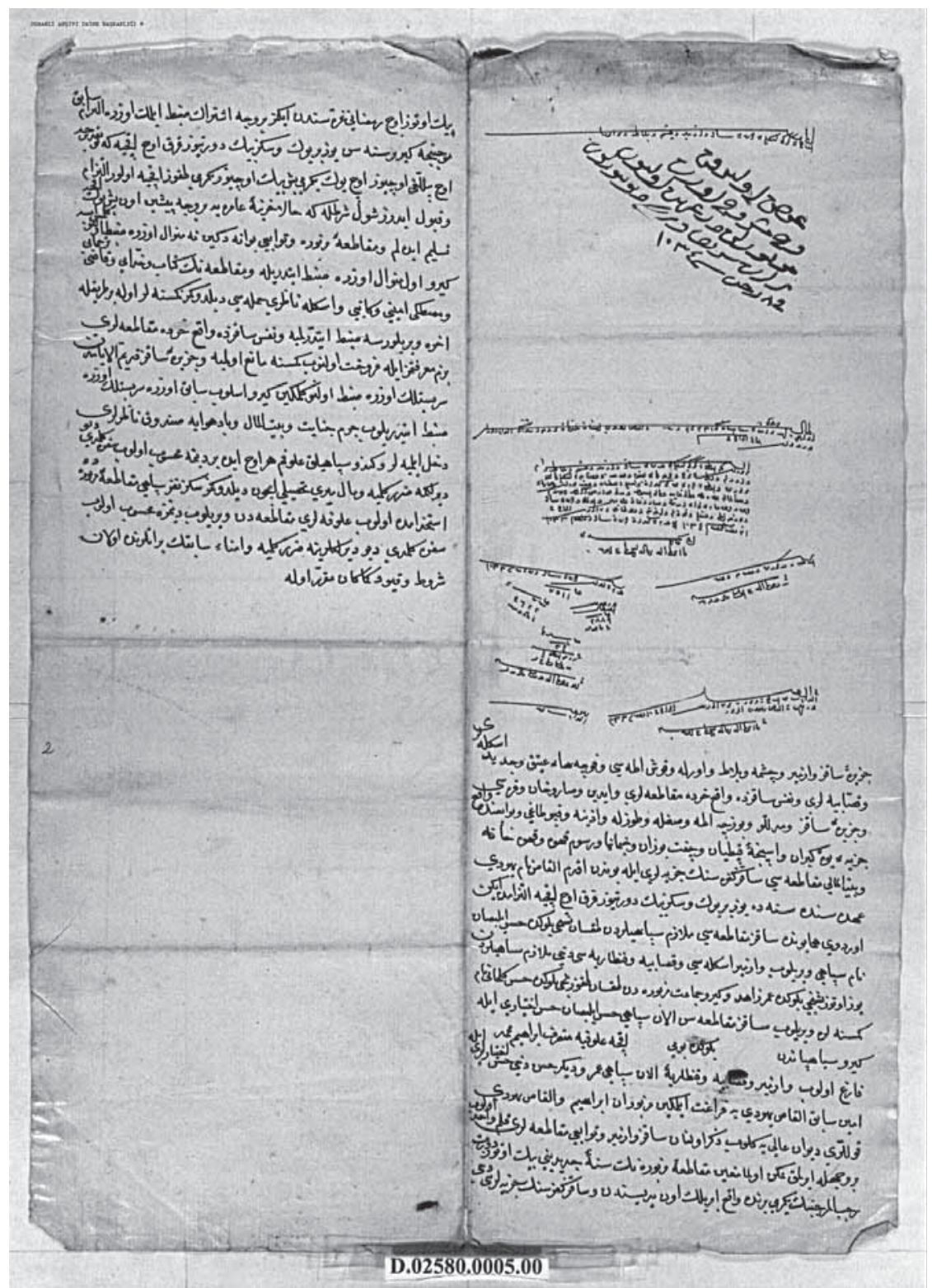


Belge 2: TS.MAD, 02580.0010.00

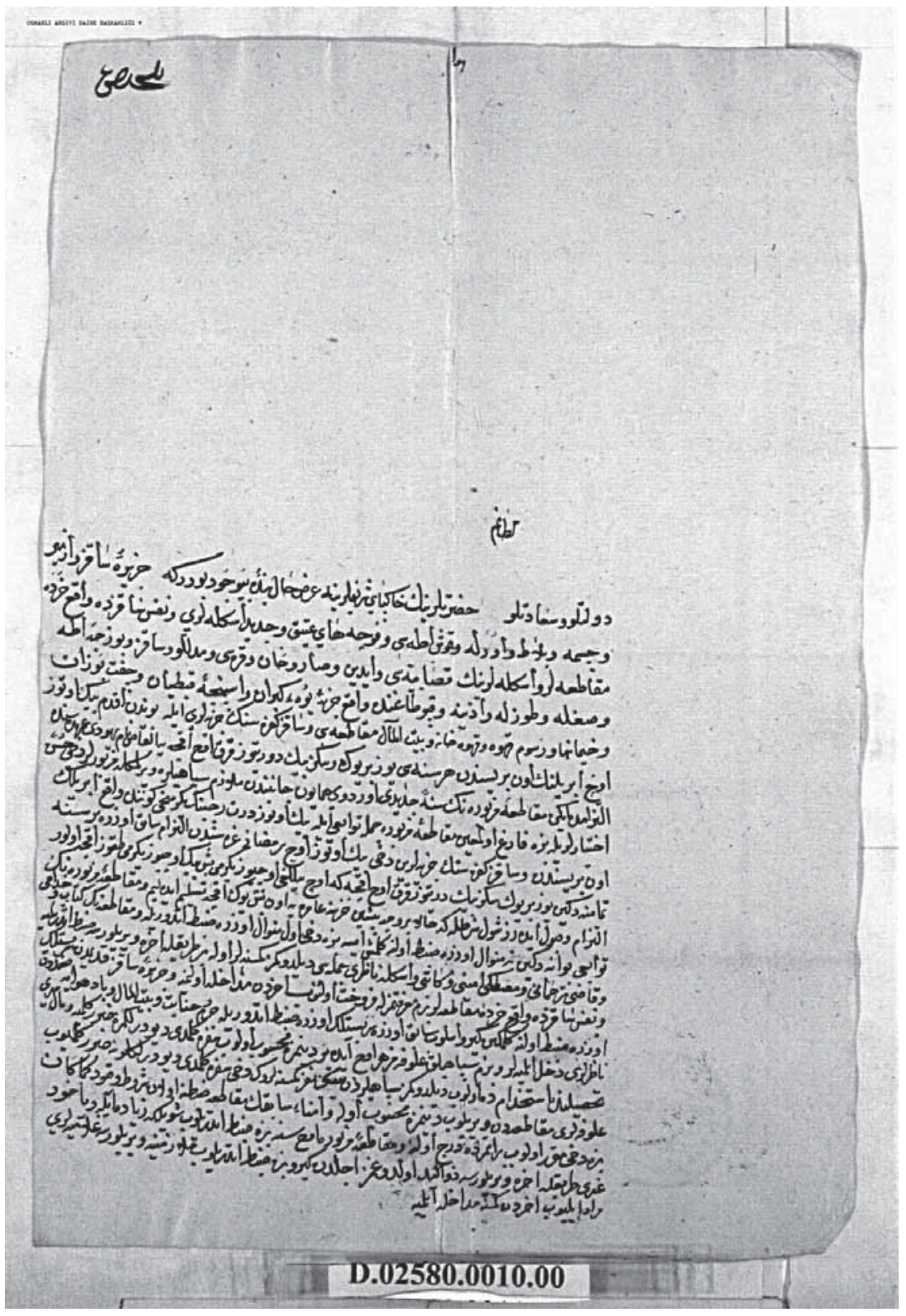


Belge 3: TS.MAD, 02580.0016.00

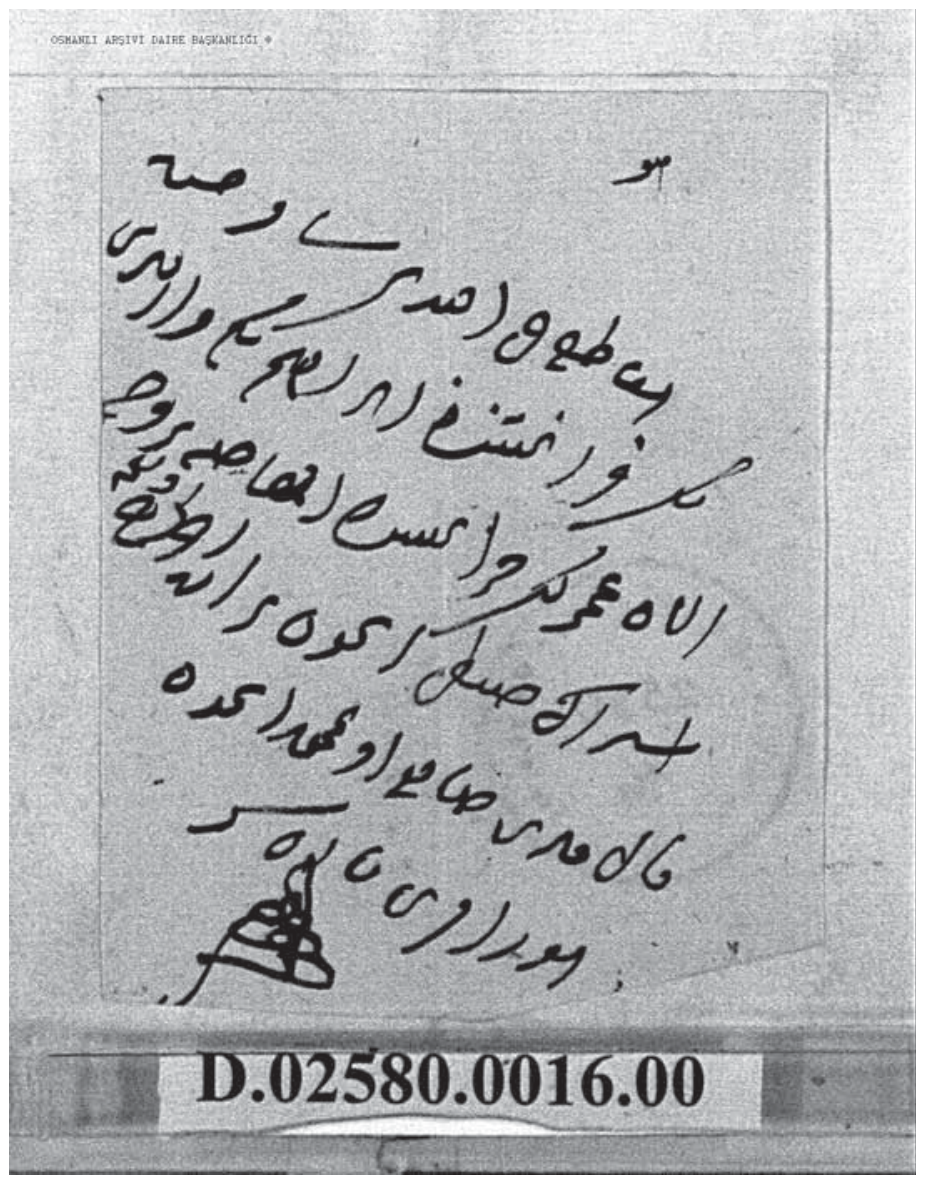


Belge 4: BOA, TS.MAD, 02580.0019.00

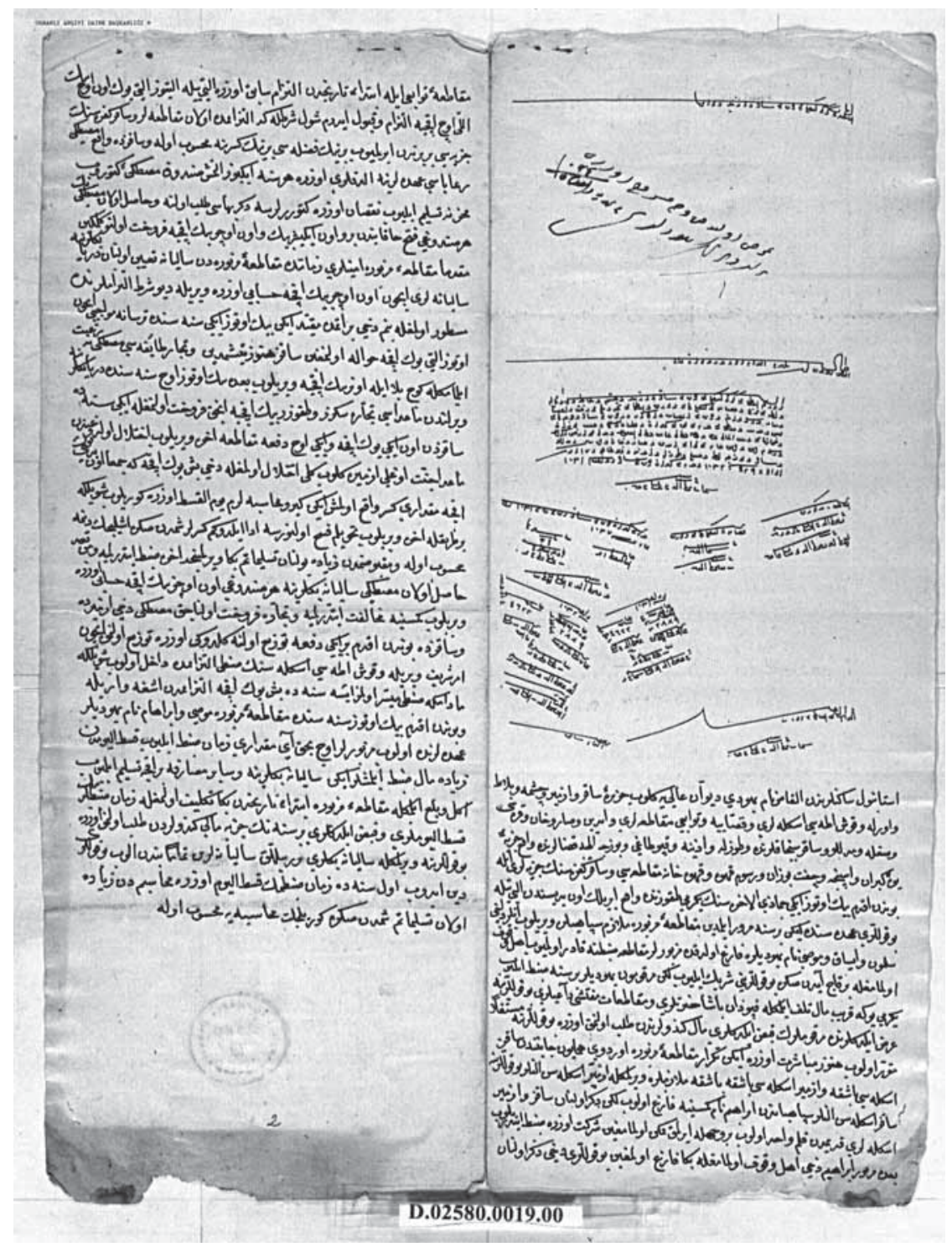


Belge 5: TS.MAD, 02580.0021.00

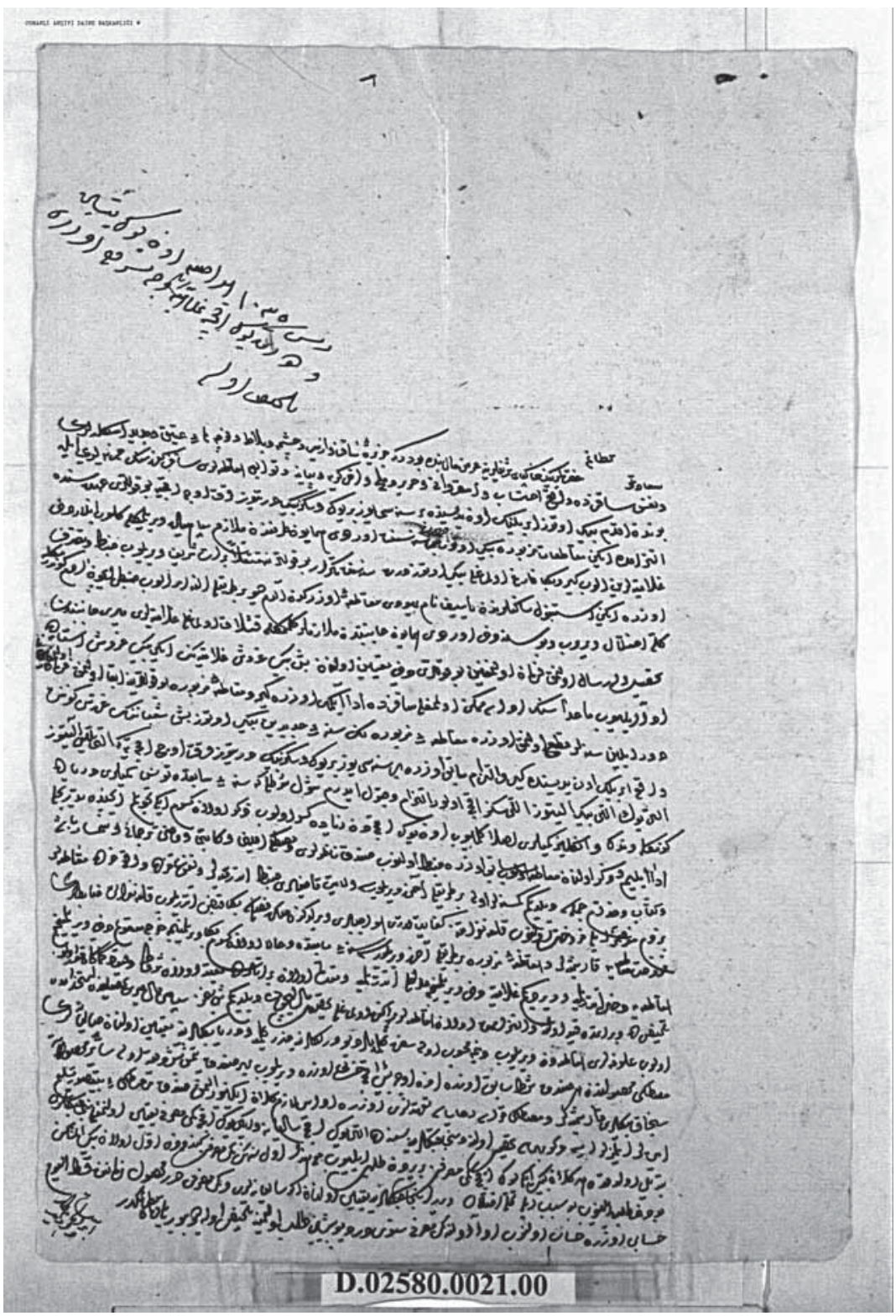


Belge 6: TS.MAD, 02580.002.00

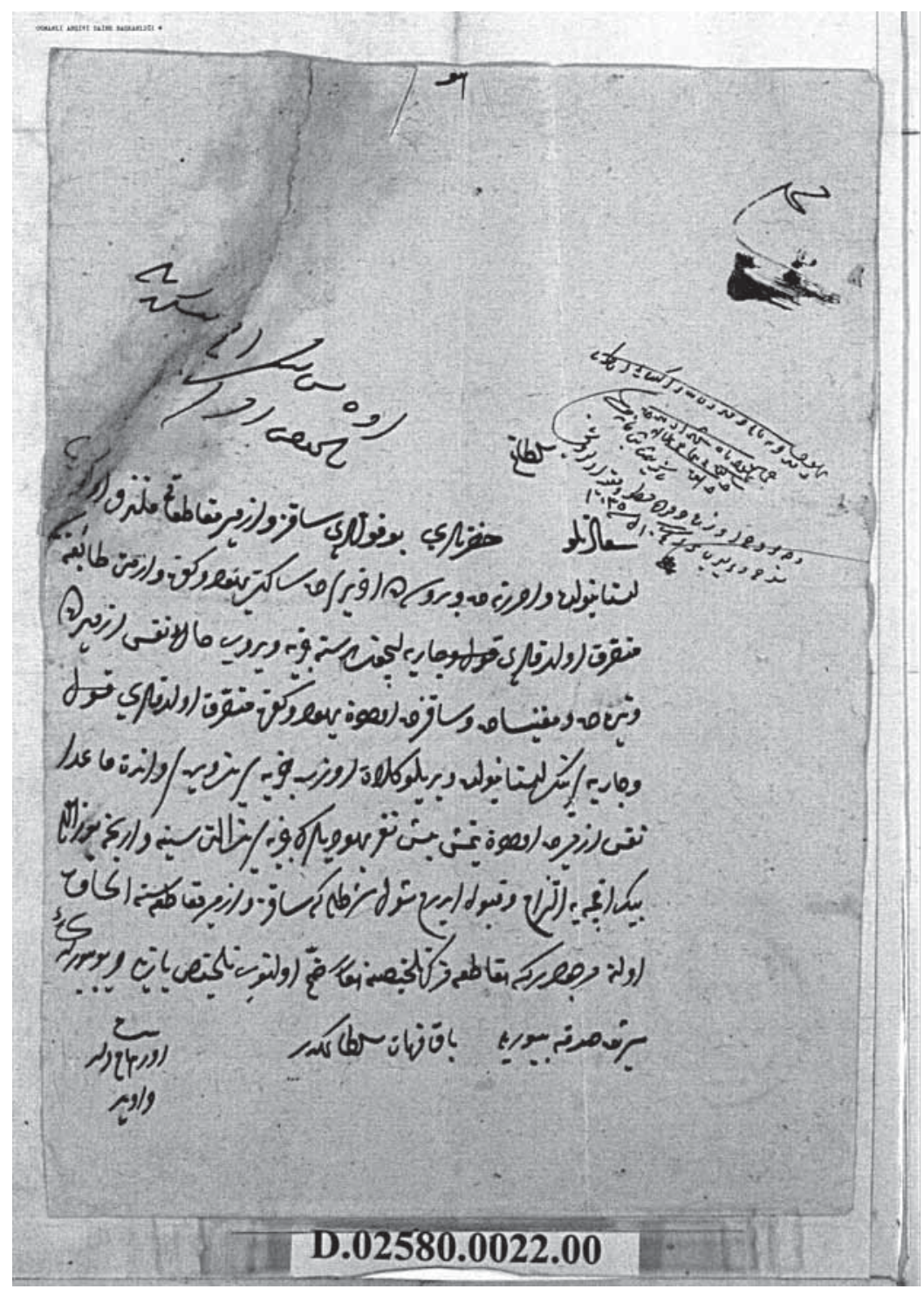


Belge 7: TS.MAD, 02580.0026.00

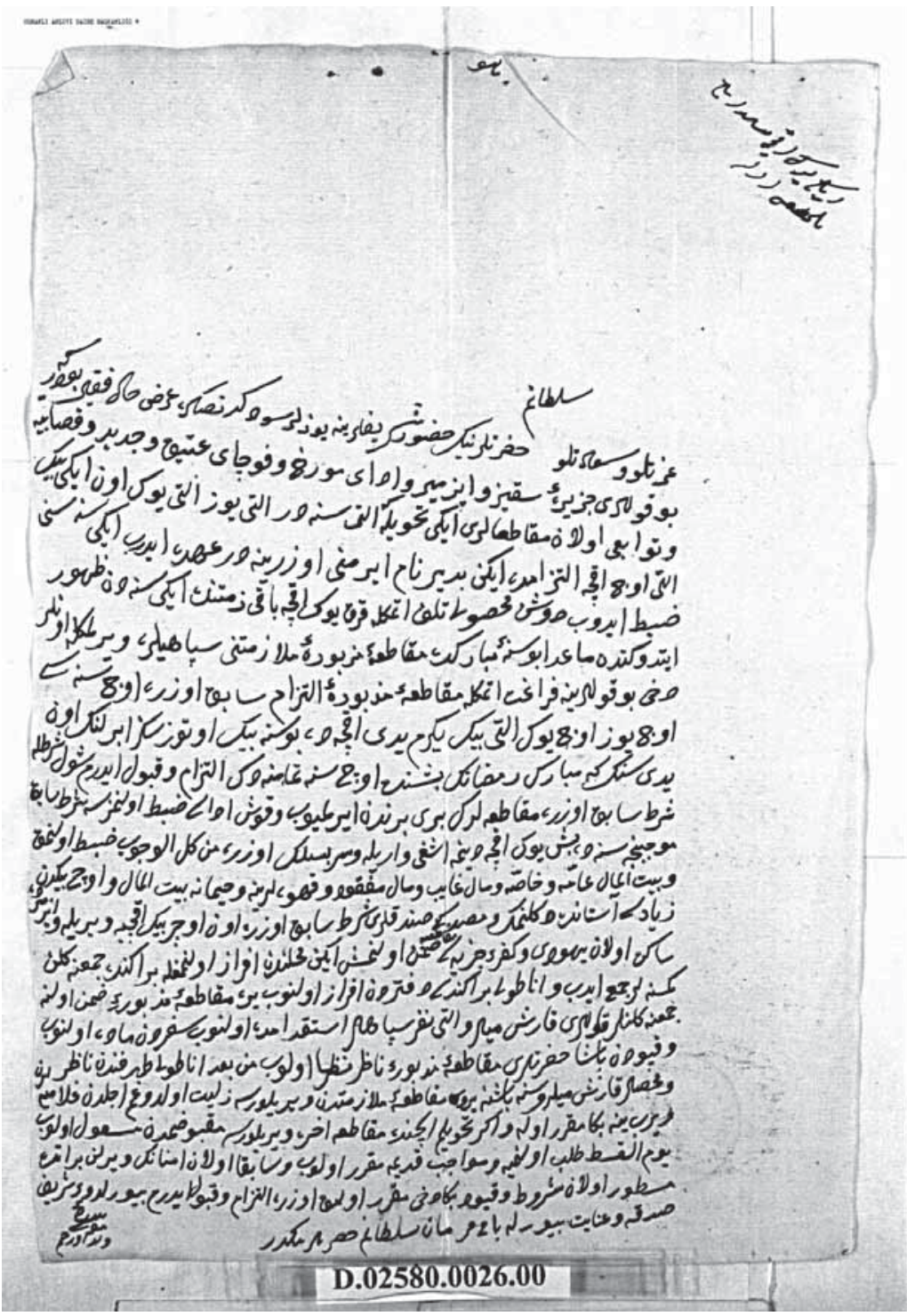




\section{Kaynaklar}

\section{Arşiv Kaynakları (Başbakanlık Osmanlı Arşivi, BOA)}

BOA, Bursa Mukataası Kalemi Defterleri (D.BRM, d.) 24248.

BOA, Başmuhasebe Kalemi Defterleri (D.BŞM.d), $\quad 00099$

BOA, İstanbul Mukataası Defterleri (D.İSM.d), 25364.

BOA, Maliyeden Müdevver Defterler (MAD), $\quad 3247 ; 6209$.

Topkapı Sarayı Maliyeden Müdevver Defterleri (TS-MAD), $\quad$ 2575; 2580; 4183; 7290.

\section{Yayınlanmış Ana Kaynaklar ve Arşiv Kaynakları}

6 Numaralı Mühimme Defteri (972 / 1564-1565) Özet-Transkripsiyon ve Indeks, II, Ankara: Başbakanlık Devlet Arşivleri Genel Müdürlüğü Yayınları 1995.

Mecdi Efendi, Şakayıkı Numaniye Tercümesi, İstanbul 1269.

Peçevî İbrahim Efendi, Tarihi- Peçevî, Cild: 1, Marmara Üniversitesi İlahiyat Fakültesi Kütüphanesi, Kayıt No: 9614

Tevârih-i Âli Osman'dan Assıkpaşazâde Tarihi, Matbaa-i Amire, İstanbul 1332.

\section{Araştırmalar}

Abun-nasr, Jamil M: "The Beylicate in Seventeenth-Century Tunisia”, International Journal of Middle East Studies, vol. 6, no. 1 (Jan., 1975), Cambridge University Press, s. 70-93.

Akdağ, Mustafa: Celali İsyanları (1560-1603), Ankara: Ankara Üniversitesi Dil ve TarihCoğrafya Fakültesi Yayınları 1963.

Ben-Naeh, Yaron: Jews in the Realm of the Sultans: Ottoman Jewish Society in the Seventeenth Century, Tübingen 2008.

Bostan, İdris: "Salyane", TDV İslâm Ansiklopedisi, XXXVI (İstanbul 2009), s. 59-60.

Çakır, Baki: Osmanlı Mukataa Sistemi (XVI-XVIII. Yüzyıl), İstanbul: Kitabevi Yayınları 2003.

Çizakça, Murat: "Tax-Farming and Resource Allocation in Past Islamic Societies", JKAU: Islamic Econ, vol. 1, s. 59-80.

Darling, Linda: Revenue-Raising and Legitimacy Tax Collection and Finance Administration in the Ottoman Empire, 1560-1660, Leiden: E.J. Brill Publishing 1996.

Demirtaş, H. Necati: Açıklamalı Osmanlı Fetvâları, II, İstanbul: Kubbealtı Neşriyat 2012.

Emecen, Feridun: "Sakıı Adasının Sakızları: Küçük Bir Osmanlı Tarım İşletmesi”, Osmanlı Araştırmaları, c. 37 (2011), s. 1-16. 
Erdoğan, Emine: “Ankara Yörükleri (1463, 1523/30 ve 1571 Tahrirlerine Göre)”, OTAM (Ankara Üniversitesi Osmanl Tarihi Araştırma ve Uygulama Merkezi Dergisi), sayı 18 (2005), s. 119-135.

Faroqhi, Suraiya: "Trade And Revenue Collection In Later Sixteenth-Century Salonica”, Oriente Moderno, nuova serie, anno 20 (81), nr. 1, The Ottomans And The Sea (2001), s. 97-108.

Fodor, Pál: "Fur of Lynx and Arable Land: The Wealth of an Ottoman Tax Farmer in the Early Seventeenth Century", Oriens, vol. 37 (2009), s. 191-208.

...... "Some Notes On Ottoman Tax Farming In Hungary", Acta Orientalia, Academiae Scientiarum Hungaricae, vol. 54, no. 4 (2001), s. 427- 435.

Genç, Mehmet: "İltizam”, TDV İslâm Ansiklopedisi, XXII (İstanbul 2000), s. 154-158.

......, "Mukâtaa", TDV İslâm Ansiklopedisi, XXXI (İstanbul 2006), s. 129-132.

Gerber, Haim: "Jewish Tax-Farmers in the Ottoman Empire in the 16th and 17th Centuries", Journal of Turkish Studies, 1986, vol. 10, s. 143-154.

Gökbilgin, Tayyip: ”XVI. Asırda Mukâtaa ve İltizam İşlerinde Kadılık Müessesesinin Rolü”, IV. Türk Tarih Kongresi Zabıtları (Ankara 1952), s. 433-444.

Groepler, Eva: İslâm ve Osmanlı Dünyasında Yahudiler, Türkçesi: Süheyla Kaya, İstanbul: Belge Yayınları 1999.

Halaçoğlu, Yusuf: "Osmanlı Belgelerine Göre Türk-Etrak, Kürd-Ekrad Kelimeleri Üzerine Bir Değerlendirme", Belleten. Cilt LX, sayı 227 (Ankara, 1996), s. 139-146.

Hegyi, Klára. "The Financial Position of The Vilayets in Hungary in the 16th -17th Centuries", Acta Orientalia Academiae Scientiarum Hungaricae, vol. 61, no. 1/2 (March 2008), s. 77-85.

Heyd, Uriel: "The Jewish Communities of Istanbul in the Seventeenth Century" Oriens, vol. 6, no. 2 (Dec. 31, 1953), s. 299-314.

İlgürel, Mücteba: "Anadolu (Anadolu İsyanları)", TDV İslâm Ansiklopedisi, III (İstanbul 1991), s. 117-119.

İnalcık, Halil: "Bursa and the Commerce of the Levant ", Journal of the Economic and Social History of the Orient, vol. 3, no. 2 (Aug., 1960), s. 131-147.

......, Osmanlı Imparatorluğu'nun Ekonomik ve Sosyal Tarihi Cilt 1 1300-1600, çev. Halil Berktay, İstanbul: Eren Yayınları 2004.

Kılıç, Orhan: "Ocaklık”, TDV İslâm Ansiklopedisi, XXXIII (İstanbul 2007), s. 317-318.

Kuzucu, Serhat: "XVIII. Yüzyılda Uluslararası Bir Sorun Olarak Garp Ocakları'nın Akdeniz'deki Korsanlık Faaliyetleri”, Gazi Akademik Bakıs, c. 9, sayı 17, 2015, s. 165-180.

Lewis, Bernard: İslâm Dünyasında Yahudiler, Ankara: İmge Kitabevi 1996. 
Matthews, John A. ve Keith R. Briffa: "The 'Little Ice Age: Re-Evaluation of an Evolving Concept", Geografiska Annaler. Series A, Physical Geography, vol. 87, no. 1, Special Issue: Climate Change and Variability (2005), s. 17-36.

Matuz, Joseph E.: "Contributions to the Ottoman Institution of the İltizam", Osmanl Araştırmalar XI (1991), s. 237- 249.

Nielsen, Randall: "Storage and English Government Intervention in Early Modern Grain Markets”, The Journal of Economic History, vol. 57, no. 1 (Mar., 1997), s. 1-33.

Olson, Robert W.: "Jews in the Ottoman Empire in Light of New Documents", Jewish Social Studies, vol. 41, no. 1 (Winter, 1979), s. 75-88.

Örenç, Ali Fuat: "Sakız Adası”, TDV İslâm Ansiklopedisi, XXXVI (İstanbul 2009), s. 6-10.

Özcan, Abdülkadir: "Pençik”, TDV İslâm Ansiklopedisi, XXXIV (İstanbul 2007), s. 226.

Özcan, Tahsin: "Pazar", TDV İslâm Ansiklopedisi, XXXIV (İstanbul 2007), s. 206-208.

Pala, Ayhan: XV ve XVI. Yüzyzllarda Selanik Şehri (Doktora Tezi), Ankara: Ankara Üniversitesi Sosyal Bilimler Enstitüsü, 1991.

Pamuk, Bilgehan: "XVII. Asırda Gümüşhane (Canca) Maden Mukataasına Dair Bazı Bilgiler”, Atatürk Üniversitesi Türkiyat Araștırmaları Enstitüsü Dergisi, 30 (2006),s. 167-184.

Rozen, Minna: A History of the Jewish Community in Istanbul: The Formative Years, 14531566, Leiden 2010.

Sahillioğlu, Halil: "Bir Mültezim Zimem Defterine Göre XVI. Yüzyıl Sonunda Osmanlı Darphane Mukataları”, İstanbul Üniversitesi İktisat Fakültesi Mecmuası, 23 (196263), s. 145-218.

Sezen, Tahir: Osmanl Yer Adları (Alfabetik Sirayla), Ankara 2006.

Shaw, Stanford J.: The Jews of the Ottoman Empire and the Turkish Republic, New York 1991.

Shmuelevitz, Aryeh: The Jews of the Ottoman Empire in the Late Fifteenth and the Sixteenth Centuries, Brill Publishing, Leiden 1984.

Uzunçarşılı, İsmail Hakkı: Osmanlı Devletinin Saray Teşkilâtı, Ankara: Türk Tarih Kurumu Basımevi, 1988.

Ünal, Mehmet Ali: XVI. Yüzyılda Çemişgezek Sancă̆ı, Türk Tarih Kurumu Basımevi, Ankara: 1999.

"XVI. Yüzyıl Sonlarında Bir İltizam Sözleşmesi”, Tarih İncelemeleri Dergisi, sayı 6, Yil 1991, s. 59-77.

White, Sam: The Climate of Rebellion in The Early Modern Ottoman Empire, Cambridge University Press, New York 2011.

Yeniçeri, Celal: İslâm İktisadının Esasları, İstanbul: Şamil Yayınevi, 1980. 